\title{
THE ECOLOGY OF THE AMPHIPODA OF THE SOUTH OF THE ISLE OF MAN
}

\author{
By N. S. Jones, M.Sc. \\ Department of Zoology, University of Liverpool
}

(Text-figs. I, 2)

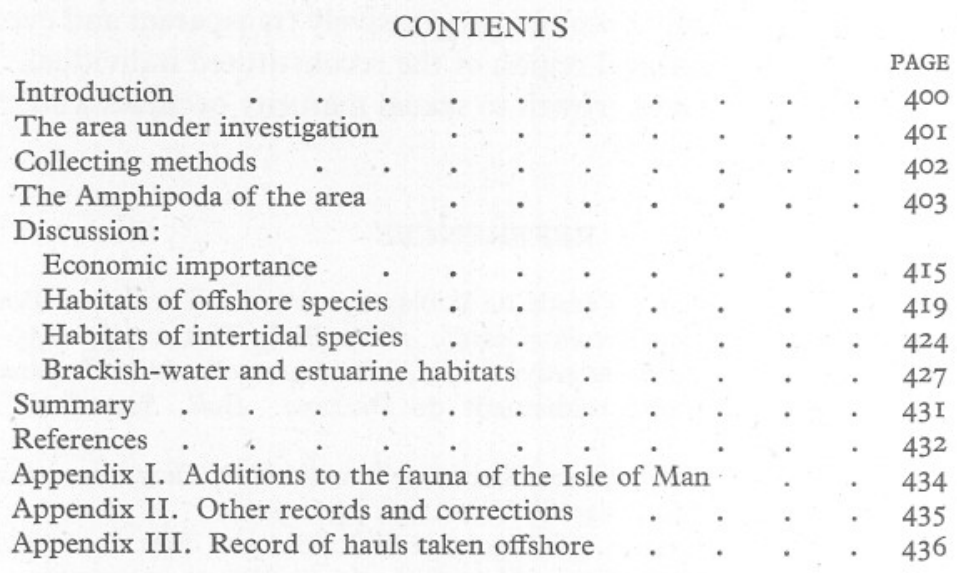

\section{INTRODUCTION}

An ecological survey of the Amphipoda on the shores of the Port Erin district was begun in November 1939. After a few months the work was interrupted by the war, but was recommenced early in 1946. In the later period the survey was extended to include the offshore grounds.

The object of the survey was in general to revise the records of the Amphipoda of the area and to obtain an estimate of the relative abundance of the species present, and in particular to provide additional information about the habitat of each species. It was thought that valuable results would be obtained by intensive collecting over a restricted area.

The majority of the records previously published were made by A. O. Walker over 50 years ago, but a few additions have been made since (Moore, I937). It is interesting to note that of I2I species previously known II4 were collected during 1946-47. The remaining seven have each been recorded on only one occasion and are probably very scarce. An additional thirty-five species are here recorded for the first time (Appendices I and II). Some of these additions are due to recent taxonomic revisions such as that on 
Marinogammarus (Sexton \& Spooner, 1940), but the majority are the result of more intensive and specialized collecting of the order. The total number of species now known from the area is 156 .

The taxonomy of the Amphipoda has been fairly well worked out in British waters. Although certain genera would repay revision there are probably very few species occurring around the British Isles that have not been described, except perhaps in the deep water to the west of Ireland. During the course of this work not one individual was obtained that could not be referred to an existing species.

It is not possible in a survey covering a large number of species to work on strict quantitative lines. On most types of shore exact quantitative methods are difficult to achieve and offshore they can only be attained on suitable ground by the use of the bottom-sampler which is not an ideal instrument for the collection of small Crustacea. However, in the course of a large number of shore collections and dredgings a fair estimate can be made of the relative abundance of the species found. Often the numbers were greater than had been expected.

Information on the habitats of amphipod species is generally limited, except for those of a few genera which have been recently revised and those of intertidal sands and of estuaries. The more important papers published with reference to this aspect are those of Reibisch (1905-6), Crawford (I937 $a, b, c$ ), Elmhirst (I93I), Southern (I9I5) and Watkin (194I). Lists of species from various habitats are given by Chevreux \& Fage (I925) and Stephensen (I929). Pirlot $(1932 a, b, c)$ discusses the influence of a burrowing mode of life and a tendency towards parasitism upon the mouthparts of Amphipoda.

\section{THE AREA UNDER INVESTIGATION}

The area within which this survey was made included the coastline within a radius of to miles from Port Erin. Some stations were worked more intensively than others, but collections were made at sufficient localities to be representative of the whole shore. The offshore work was mainly carried out in depths of less than $40 \mathrm{~m}$. within a few miles of Port Erin Bay. Some hauls were taken in depths down to $84 \mathrm{~m}$. at distances up to Io miles from Port Erin, but the deeper water cannot be considered thoroughly investigated.

A description of the shores near Port Erin with charts is included in Moore (I937) and the closer offshore grounds are dealt with by Jones (I940). It may be added that the sea bottom slopes gradually to a depth of about $45 \mathrm{~m}$. at a distance of roughly 6 miles from the coastline and thereafter more steeply down to about $85 \mathrm{~m}$. in a further 2-3 miles. In depths of $45-80 \mathrm{~m}$. the bottom consists for the most part of muddy sand, the silt-content increasing with the depth. In over $80 \mathrm{~m}$. the deposit is clay or mud. 


\section{Collecting Methods}

On the shore all likely habitats were searched, the amphipods found being placed in tubes and taken to the laboratory for examination. Notes were made on the spot of the abundance or otherwise of species that could be recognized, and each part of the collection was referred to the nearest tidal level.

On rocky facies the specimens were obtained by turning over stones and boulders and searching among algae. Pools were investigated and the fauna collected with a hand net. A net was used for collecting among algae at the edge of the tide. Laminaria holdfasts were removed complete and searched for animals in the laboratory.

Sandy beaches were investigated by sieving $\frac{1}{4}$ sq.m. samples, and by collecting specimens found under stones and among algae at low-water mark.

Particular attention was paid to fresh-water streams emptying over the beach and to the Silverburn, a small river with its estuary at Castletown.

On the offshore grounds all types of gear were used except the bottomsampler, in particular the following: (i) naturalist's dredge with $2 \mathrm{ft} .6$ in. mouth and a bag of heavy $\frac{1}{2}$ in. mesh; (ii) scallop dredge with $3 \mathrm{ft}$. mouth and a bag lined with shrimp netting; (iii) small otter trawl; (iv) two dredge frames, $\mathrm{I} \mathrm{ft.} 6$ in. and $2 \mathrm{ft}$. 6 in. across respectively, each with a bag made of sacking material; (v) D-net with canvas bag; (vi) coarse tow-net attached to the back of the otter trawl.

The first two, the naturalist's dredge and the scallop dredge, were not very successful, as part of the contents was washed out, and often only those species were obtained which were clinging to hydroids, etc., attached to stones and shells. The small otter trawl (iii) suffered from the same disadvantage and could be used only on smooth bottoms: it was useful, however, for collecting loose algae. The dredge frames with sacking (iv) were the most useful instruments. They can be used on any type of ground. They fill up almost immediately and bring up the deposit intact so that a fairly true estimate can be made of the habitat of animals found among the contents. It is necessary to attach a heavy weight to the rope a few feet in front of the dredge, and it is an advantage to have the mouth bowed out so that it will dig into the substratum. The D-net (v) was not successful: it could only be used on sand or mud and merely skimmed the surface. This may have been due to faulty construction, but its use is limited. The coarse tow-net (vi) was the most successful instrument for collecting numbers of species and individuals but it has the following disadvantages: it must be towed over a long distance and can only be used in conjunction with a trawl or dredge, and it does not provide any indication of the type of bottom over which it has travelled. It is therefore necessary to sample the deposit by other means, or to use the tow-net only on ground which is already known. The silk is easily torn on rough ground. 
It is probable that a net such as that described for catching bottom plankton by Russell (I928), with slight modification to stir up the bottom, would be an excellent instrument for capturing Amphipoda, but I have had no opportunity of using it.

Wherever possible the whole of the contents of the dredge or other instrument were brought back to the laboratory and searched for amphipods. I consider it essential to adopt this procedure as it is usually impossible to look through the material thoroughly in a small boat. With the fine-meshed dredge the most satisfactory method of obtaining the specimens is to place the contents in shallow dishes with sufficient sea water just to cover them. The deposit is stirred and the dish gently tilted from side to side. Most species of amphipod are eventually caught in the surface film, though the process may take a long time. Fine sand and mud may be passed through sieves but it is difficult to sieve coarse deposits and many small forms will be missed.

The numbers of each species were recorded for each haul. The bottom deposits were occasionally analysed by sieving and weighing the separated constituents but most were graded by visual observation. Positions at sea were ascertained by means of bearings taken on prominent landmarks with a prismatic compass, and soundings were taken with a line.

A list of hauls is given in Appendix III (p. 436).

A representative collection of the species obtained is held at the Marine Biological Station, Port Erin.

\section{THE AMPHIPODA OF THE AREA}

There follows a systematic list of species obtained with locations and habitats. Offshore collections made during 1946 are summarized in Table I (p. 4I6). Under each species, where possible, a short general statement of habitat is given, compiled from my observations in conjunction with previously published work. A number of records made during 1947 from bottom-sampler hauls but not tabulated are included.

I have not included geographical range except where this is extended, as it is adequately dealt with by Chevreux \& Fage (I925), Norman \& Scott (I906), Stephensen (1929 and 1935-42), and Tattersall (I9I3).

The division of hauls into sections according to habitat in Table I was carried out from notes of the contents of the instrument used and from previous knowledge of the area. When two different types of ground were traversed in one haul, as happened with the otter trawl and tow-net, I have placed the hauls in a mixed section. Allocation to one section is sometimes arbitrary, but I have been guided by experience and any error is likely to be small.

Tidal levels are referred to by their usual abbreviations (H.w.S., H.w.N., M.T.L., L.W.N. and L.W.S.). A prefixed E. denotes 'extreme'. 
Abbreviations for place-names include I.O.M. for Isle of Man, P.E. for Port Erin, and P.StM. for Port St Mary.

The terms 'shallow', 'deep', etc., as applied to the bathymetrical range of a species, refer only to the littoral system, i.e. depths of less than $200 \mathrm{~m}$.

\section{LYSIANASSIDAE}

\section{Gammaridea}

Acidostoma obesum (Bate): usually in muddy sand at moderate depths. I.O.M.: 59-75 m., muddy sand, few.

Euonyx chelatus Norman: in moderately deep water; possibly always associated with Echinus esculentus. I.O.M. : 36-46 m., in dredge hauls with Echinus, few.

Nannonyx goësi Boeck: mainly at and near low-water mark among algae, and occasionally on hydroids in deeper water. I.O.M.: intertidal, in Laminaria holdfasts, P.StM. Ledges and Outer Harbour, few. Offshore: $60 \mathrm{~m}$., on hydroids, one.

$N$. spinimanus Walker: no reliable estimate can be made of its habitat as the records of its occurrence are too few. I.O.M.: on Maia squinado, L.w.s., Langness Point, one.

Lysianassa plumosa Boeck: on coarse or mixed grounds in moderate depths. I.O.M.: I I-55 m., particularly on mixed grounds, fairly common.

Perrierella audouiniana (Bate): mainly in sponges in moderately deep water, but may occasionally be found on hydroids or algae. I.O.M.: $33-82 \mathrm{~m}$., on hydroids and in sponges, few.

Orchomene humilis (Costa): usually in shallow water on algae or hydroids. I.O.M.: intertidal, in Laminaria holdfasts, Poyllvaaish, few. Offshore: $22-33 \mathrm{~m}$., on algae and hydroids, few.

Socarnes erythrophthalmus Robertson: most abundant in fine gravel in shallow water but may also be found on fine sand. I.O.M.: intertidal: in fine sand at low water, P.E. Bay, few. Offshore: $2-18 \mathrm{~m}$., in stony gravel and fine sand, abundant.

Hippomedon denticulatus (Bate): burrowing in sand of all grades, usually in fairly shallow water. I.O.M.: 9-33 m., fine and coarse sand, few.

Scopelocheirus crenatus Bate: usually on muddy sand or muddy gravel in moderate depths. Carnivorous and probably acts as a scavenger. I.O.M.: 27-82 m., particularly on muddy sand, few.

Tryphosa sarsi Bonnier: on sandy bottom in shallow water. Probably feeds on sponges and acts as a scavenger. I.O.M.: intertidal: on sponges at L.w.s., Chapel Bay, few. Offshore: 4-9 m., on muddy sand and abundant on dead fish.

Tmetonyx similis (G. O. Sars): has a wide bathymetrical diștribution and seems usually to occur on mixed grounds. I.O.M.: 22-27 m., on coarse sand and broken shell, one.

Tryphosites longipes (Bate \& Westwood): on muddy ground in moderate depths. I.O.M.: 68 m., muddy sand, few.

Orchomenella nana (Kröyer): commonly found on sand or mixed grounds in fairly shallow water. There are a number of records of its occurrence in dead crabs and it seems to be attracted by crustacean flesh. I.O.M. : 23-33 m., particularly on coarse sand and broken shell, fairly common.

\section{AMPELISCIDAE}

Ampelisca brevicornis (Costa): burrowing in muddy sand, usually in shallower water than the other species of the genus. I.O.M.: intertidal, in muddy sand at L.W.S., P.StM. Outer Harbour, few. Offshore: 2-I8 m., fine sand, few. 
A. macrocephala Lilljeborg: burrowing in mud in moderate depths. I.O.M.: 75 m., very muddy sand, one.

A. spinipes Boeck: burrowing in mixed grounds in moderate depths. Many of the records are from gravels and coarse grounds. Apparently never occurs in fine sand without mud. I.O.M. : $18-82 \mathrm{~m}$., particularly in muddy sand, fairly common.

A. diadema (Costa): burrowing in muddy and mixed grounds mainly in water of moderate depth. In common with the other species of the genus it is a suspension feeder (Hunt, 1925). I.O.M.: I8-59 m., muddy sand and muddy sand with broken shell, fairly common.

A. typica (Bate): burrowing in coarse deposits usually in fairly shallow water. I.O.M.: I I-6I m., particularly in gravel and mixed grounds, few.

A. tenuicornis Lilljeborg: habitat similar to that of $A$. diadema. I.O.M.: I I-82 m., usually in muddy sand or muddy sand with broken shell, fairly common.

\section{ARgISSIDAE}

Argissa hamatipes (Norman): probably burrowing in fine or coarse deposits containing mud. I.O.M.: I5-38 m., on mixed grounds, rare.

\section{HAUSTORIIDAE}

Bathyporeia guilliamsoniana (Bate): burrowing in fine or muddy sand at L.w.s. and in shallow water. I.O.M. : intertidal, in muddy sands at L.w.S., Chapel Bay and P.StM. Outer Harbour, few. Offshore: 2-18 m., in fine sand, common.

B. elegans Watkin: burrowing in fine sand at L.W.S. and in shallow water. Its bathymetrical range is roughly the same as that of B. guilliamsoniana but it probably prefers cleaner sand and is usually more abundant than the latter species. I.O.M.: intertidal, in sand at L.W.S., P.E. Bay and P.StM. Outer Harbour, few. Offshore: $2-15$ m., fine sand, abundant.

B. pelagica Bate: strictly intertidal, burrowing in fine sand below H.W.N. Its optimum zone is from M.T.L. to L.W.N. I.O.M.: in fine sand from H.W.N. downwards, P.E. Bay and Brewery Beach, common.

B. gracilis G. O. Sars: does not occur between tide-marks. May inhabit coarser sand than the other species in the genus and is confined to deeper water. I.O.M.: I I-35 m., mainly in coarse sand, few.

Haustorius arenarius (Slabber): usually intertidal, burrowing in sand. Its optimum zone is probably about the level of H.W.N. I.O.M. : in fine sand from H.W.N. to L.W.N., common.

Urothoë brevicornis Bate \& Westwood: burrowing in fine sand from M.T.L. downwards and in shallow water. I.O.M. : not found below low-water mark. In fine sand from M.T.L. to L.W.S., P.E. Bay, few.

$U$. elegans Bate: usually in deeper water than $U$. brevicornis and may inhabit more muddy ground. I.O.M. : intertidal, in muddy sand at E.L.W.S., P.StM. Outer Harbour and Chapel Bay, common. Offshore: 9-60 m., particularly in sand, common.

$U$. marina Bate: burrows in coarser deposits than the other species of Urothoe,, usually in coarse sand and fine gravels in moderate depths. I.O.M.: $18-37 \mathrm{~m}$., particularly in coarse sand and broken shells, few.

\section{Phoxocephalidae}

Paraphoxus oculatus G. O. Sars: probably mainly in fairly deep water, burrowing in mud or muddy sand. I.O.M.: 60 m., muddy sand, few.

Metaphoxus fultoni (T. Scott): characteristic of fine gravels, usually in rather shallow water. The animal is very small and flattened laterally and is adapted for 
burrowing in deposits consisting mainly of rather large particles. I.O.M.: I I-60 m., particularly in gravel, common.

Harpinia antennaria Meinert: burrowing in muddy sand, usually in fairly shallow water but may extend down to moderate depths. It is often found in company with other species of the genus, particularly $H$. pectinata. I.O.M. : intertidal, muddy sand at E.L.W.S., P.StM. Outer Harbour, fairly common. Offshore: I I-82 m., particularly in muddy sand, few.

$H$. pectinata G. O. Sars: burrowing in muddy sand or mud. Has not been recorded from between tide-marks. I.O.M. : 46-88 m., in muddy sand, few. In the Irish Sea it usually occurs in deeper water than $H$. antennaria but the two species overlap.

H. crenulata Boeck: burrows in mud, usually in rather deep water. I.O.M.: 59-88 m., muddy sand and mud, fairly common.

\section{AMPHILOCHIDAE}

Amphilochus manudens Bate: probably lives mainly among hydroids in moderate depths. I.O.M.: I I-37 m., particularly on hydroids and mixed grounds, fairly common.

A. spence-batei (Stebbing): perhaps usually on muddy sand but the species has been too seldom recorded for a reliable estimate to be formed. The other British records are from Torbay and Plymouth. I.O.M.: I5-18 m., on gravel and sand, rare.

Amphilochoides serratipes (Norman): on mixed ground with mud at moderate depths. I.O.M.: $27-33 \mathrm{~m}$., on muddy sand with broken shell, few. The species was obtained in six hauls, all on the same type of ground.

Peltocoxa brevirostris (T. \& A. Scott): on mixed grounds in moderate depths. The animal is very small, usually about $\mathrm{I} \mathrm{mm}$. in length, and may live interstitially. I.O.M.: 27-33 m., on mixed grounds, fairly common.

Gitana sarsi Boeck: usually in shallow water on algae and hydroids and in gravel. Occasionally occurs at low-water mark. I.O.M.: intertidal, in Laminaria, P.StM. Ledges, few. Offshore: 7-82 m., particularly on gravel and mixed grounds, common.

\section{LEUCOTHOIDAE}

Leucothoë spinicarpa (Abildgaard): commensal in sponges and the branchial sacs of ascidians, usually in fairly deep water but at low-water mark in suitable localities. I.O.M.: intertidal, in sponges, Poyllvaaish, few. Offshore: $60 \mathrm{~m}$., in sponges, few.

L. lilljeborgi Boeck: on muddy sand or mud in which it probably burrows, as suggested by Crawford (I937b). I.O.M.: I I $-88 \mathrm{~m}$., usually on muddy ground, few.

\section{STENOTHOIDAE}

Metopa bruzelii Goës: usually associated with hydroids in fairly shallow water. I.O.M.: $18-33$ m., particularly on coarse sand with broken shell, fairly common.

M. pusilla G. O. Sars: habitat similar to that of M. bruzelii. I.O.M.: 33-60 m., particularly on coarse sand with broken shell, few.

M. borealis G. O. Sars: habitat probably similar to that of $M$. bruzelii but it may extend into deeper water. The three species may occur together. I.O.M.: I8-82 m., particularly on mud, few.

Stenothoë monoculoides (Montagu): occurs mainly above low-water mark but may extend into shallow water. Inhabits algae and is particularly common among Corallina in pools from M.T.L. to L.W.N., and in Laminaria holdfasts at L.W.S. Occasionally found on sponges. I.O.M.: occurs throughout the area and is abundant in Corallina pools and in Laminaria holdfasts. Intertidal: P.StM. Ledges and Outer Harbour, Poyllvaaish, below Biol. Stat., Chapel Bay, Castletown Bay. Offshore: 4-18 m., on algae, few. 
S. marina (Bate): usually on hydroids in fairly shallow water and occasionally on algae. I.O.M. : I I-55 m., particularly on hydroids, few.

$S$. antennulariae Della Valle $=S$. crassicornis Walker: probably found only on hydroids in moderately deep water, sometimes in company with S. marina. I.O.M.: $3 \mathrm{I}-60 \mathrm{~m}$., on hydroids, few.

\section{CRESSIDAE}

Cressa dubia (Bate): usually on hydroids in moderately deep water. It is fairly abundant but is probably often missed owing to its small size. I.O.M.: $22-82 \mathrm{~m}$., on hydroids and mixed ground, common.

\section{Colomastigidae}

Colomastix pusilla Grube: always associated with sponges down to moderate depths. I.O.M. : $60 \mathrm{~m}$., in sponges, few.

\section{LAPHYSTIIDAE}

Laphystius sturionis Kröyer: parasitic on fish. I.O.M.: on a cod caught on a long line, many.

\section{ACANTHONOTOZOMATIDAE}

Panoploea minuta (G. O. Sars): among algae in shallow water and may extend into moderate depths on hydroids. I.O.M. : 7-64 m., on hydroids and algae, fairly common.

$P$. eblanae (Bate): probably on hydroids in moderately deep water. Also reported in company with Rhizostoma. I.O.M.: 27-60 m., on hydroids, few.

Iphimedia obesa Rathke: habitat similar to that of Panoploea minuta but usually occurs in rather deeper water. I.O.M.: II-82 m., on hydroids and algae, few.

\section{LILLJEBORGIIDAE}

Lilljeborgia brevicornis Bruzelius: has a wide bathymetrical range. It is difficult to form an estimate of its habitat but it possibly occurs mainly on hydroids. I.O.M.: $60 \mathrm{~m}$. , on hydroids, few.

L. kinahani (Bate): on fine gravels and mixed grounds in fairly shallow water. I.O.M. : I I-55 m., on gravel and mixed grounds, common.

\section{OEDICEROTIDAE}

Perioculodes longimanus (Bate \& Westwood): burrowing in fine or muddy sand at L.w.S. and in shallow water. Occasionally extends into moderate depths. I.O.M.: intertidal, in muddy sand at extreme L.w.S., P.StM. Outer Harbour and Chapel Bay, fairly common. Offshore: 4-82 m., fine and muddy sand, common.

Pontocrates arenarius (Bate): burrows in fine sand preferably without mud from M.T.L. to a depth of a few metres. Its main centre of distribution is about L.W.S. I.O.M.: intertidal, in fine sand from M.T.L. downwards, P.E. Bay and Chapel Bay, fairly common. Offshore: 2-II m., fine sand, few.

P. norvegicus Boeck: burrows in fine or muddy sand from M.T.L. to shallow water. I.O.M.: more abundant in shallow water than between tide-marks. Extends into rather deeper water than $P$. arenarius and will burrow in muddy sand, whereas $P$. arenarius prefers clean sand. Intertidal: in fine and muddy sand, from M.T.L. downwards, P.E. Bay, P.StM. Outer Harbour, and Chapel Bay, few. Offshore: 2-I8 m., fine sand, common.

Synchelidium haplocheles Grube: in fairly shallow water but usually at a greater depth than the species of Pontocrates. Burrows in a wide range of deposits from fine 
sand to gravel. I.O.M.: 4-35 m., in fine sand, gravel and mixed grounds, fairly common.

Monoculodes carinatus Bate: usually in fairly shallow water and probably burrows mainly in rather coarse deposits. I.O.M.: I I-33 m., mixed grounds, few.

$M$. subnudus Norman: habitat similar to that of $M$. carinatus but may occur in deeper water. I.O.M.: 7-33 m., mixed grounds, few.

Westwoodilla caecula (Bate): in mud or muddy sand usually in fairly deep water. I.O.M.: $82 \mathrm{~m}$., mud, fairly common.

\section{TIRONIDAE}

Syrrhoites fimbriatus (Stebbing \& Robertson): probably mainly on mixed grounds in moderately deep water. This species has only once been found outside the Irish Sea and the Firth of Clyde, but as this record was from north of Spitsbergen it must have a much wider geographical range than would appear from the few published finds. It has probably been missed largely because of its minute size. I.O.M.: I I-55 m., mixed grounds, few.

\section{CALLIOPIIDAE}

Calliopius crenulatus Chevreux \& Fage: mainly on algae near low-water mark. I.O.M.: on sand at extreme L.w.S., P.E. Bay, few.

Apherusa cirrus (Bate): near or just below low-water mark on algae. I.O.M.: occurs particularly on Halidrys siliquosa with which it tones so well that it is difficult to distinguish. At L.w.s., Chapel Bay, Castletown Bay, Niarbyl, common.

A. bispinosa (Bate): usually on algae in shallow water and between tide-marks in pools and sheltered situations, but it may extend into fairly deep water where it probably lives on hydroids. I.O.M. : intertidal, in Laminaria holdfasts, on Halidrys and red algae at low-water mark, P.StM. Ledges and Outer Harbour, Chapel Bay, Castletown Bay, Poyllvaaish, few. Offshore: 2-59 m., mainly on algae and fine gravel, common.

A. jurinei (Milne-Edwards): among algae between tide-marks, only occasionally occurring offshore. Found in Corallina and Enteromorpha pools from H.w.N. downwards. Particularly common in the holdfasts of Laminaria digitata. I.O.M.: occurs throughout the area but is more abundant on exposed situations on rock. In sheltered places it is largely replaced by Apherusa bispinosa. Exhibits a large number of colour varieties. Intertidal: P.StM. Ledges and Inner Harbour, Poyllvaaish, Niarbyl, below Biol. Stat., Spaldrick, Chapel Bay, Castletown Bay. Offshore: 9-3I m., on algae, few.

\section{Pleustidae}

Parapleustes monocuspis (G. O. Sars): on hydroids in moderate depths. I.O.M.: 33-37 m., on hydroids, few. This species has not previously been recorded from the Irish Sea, but Walker (I895) stated that he had collected specimens on the north coast of Wales corresponding to this form, which he regarded as the young of P. bicuspis. $\mathrm{He}$ had constantly collected the two forms together and observed that only the largest specimens had a dorsal tooth on the first pleon segment, and this varied in length in proportion to the size of the specimen. It seems clear, however, from the descriptions of Sars (1895), that the two species are really distinct.

Stenopleustes nodifer (G. O. Sars): on mixed grounds and hydroids in fairly deep water. I.O.M.: $29-82 \mathrm{~m}$., on mixed grounds and hydroids, few.

\section{PARAMPHITHOIDAE}

Epimeria cornigera (J. C. Fabricius): on coarse ground and particularly on corals in rather deep water. I.O.M.: 55-84 m., mud and coarse sand with broken shell, few. 


\section{ATYLIDAE}

Nototropis swammerdami (Milne-Edwards): among algae on sandy bottoms in very shallow water and occasionally above low-water mark on sandy shores. I.O.M.: intertidal, on sand and among weed at L.w.s. P.E. Bay, Chapel Bay, Castletown Bay, fairly common. Offshore: $2-15 \mathrm{~m}$., among weed on sand, common.

N. vedlomensis (Bate \& Westwood): on mixed grounds and gravels, usually in deeper water than $N$. swammerdami. Conceals itself in the deposit in the manner described by Crawford (1937 b) for Maera othonis. I.O.M.: 7-60 m., on gravel and mixed grounds, common.

\section{MELPHIDIPPIDAE}

Melphidippella macra (Norman): habitat similar to that of Nototropis vedlomensis. The two species often occur in the same hauls. I.O.M.: 9-82 m., mainly on mixed grounds, common.

\section{EUSIRIDAE}

Eusirus longipes Boeck: usually on mixed or muddy grounds in moderate depths. I.O.M. : I I-60 m., mainly on mixed grounds, fairly common.

\section{GAMMARIDAE}

Gammarellus homari (J. C. Fabricius): among algae in shallow water and at low-water mark. I.O.M.: intertidal, among Laminaria at low-water mark and on floating buoy, P.StM. Ledges, Niarbyl, P.E. Breakwater, common. Offshore: I-I8 m., on weed, few. The specimens from P.StM. included a number of adults of the form homari while those from P.E. Bay were all of the form angulosus. I am unable to detect any morphological difference between the two forms other than the length of the projections of the dorsal carina, and therefore treat them as belonging to one species. At the same time the collections included ovigerous females about ro $\mathrm{mm}$. in length of both forms.

Cheirocratus sundevalli (Rathke): mainly on mixed grounds and gravels in moderate depths. Also occurs occasionally on loose weed. I.O.M.: 9-37 m., in gravel and mixed grounds, fairly common.

C. intermedius G. O. Sars, probably on muddy grounds in moderate depths. I.O.M.: 66-84 m., in muddy sand, few.

C. assimilis Lilljeborg: habitat similar to that of $C$. sundevalli, but usually less abundant. I.O.M.: 27 m., mixed grounds, few.

Megaluropus agilis Hoek: burrowing in fine sand in shallow water. Also occurs on loose weed. I.O.M.: 2-15 m., in fine sand and on weed, common.

Melita pellucida G. O. Sars: among decaying vegetation in slightly brackish water of salinity up to about $3 \%$. I.O.M.: upper part of Silverburn estuary, few.

M. palmata (Montagu): under stones and on algae mainly from M.T.L. to L.W.N. Can tolerate reduction in salinity down to about $13 \%$ and penetrates some distance into estuaries. I.O.M.: under stones from M.T.L. to L.W.S., P.StM. Ledges and Inner Harbour, Chapel Bay, Spaldrick, Brewery Beach, lower part of Silverburn, Niarbyl, fairly common.

$M$. hergensis Reid: habitat similar to that of $M$. palmata but probably does not penetrate estuaries and occurs from above L.W.S. to shallow water. I.O.M. : intertidal, under stones on sand at L.w.S., Chapel Bay, common. Offshore: 2-22 m., on weed on sand, few.

M. obtusata (Montagu): on sublittoral algae and occasionally at low-water mark, and also on Asterias rubens and Luidia ciliaris in deeper water. The specimens from echinoderms are coloured white, while those from algae are brown or dark coloured. 
I.O.M.: intertidal, on algae at L.w.S., P.E. Bay, Chapel Bay, P.StM. Inner Harbour, few. Offshore: II-33 m., mainly on Asterias and Luidia, common.

Ceradocus semiserratus (Bate): in fine gravels and mixed grounds usually in fairly shallow water. I.O.M.: II-55 m., on gravel and coarse sand with broken shell, common.

Maera othonis (Milne-Edwards): usually on coarse deposits mixed with fine or muddy sand in moderate depths. Occasionally at L.w.s. It shelters under pieces of shell and pebbles. I.O.M.: the most widely distributed amphipod on the offshore grounds of the area. It occurs on most types of bottom but is most abundant on mixed grounds and gravel. Intertidal: 7-82 m., gravel, mixed grounds, and hydroids, common.

Maerella tenuimana (Bate): appears to occur only in coarse sand deposits in moderate depths and to be absent from ground containing mud. Probably burrows in the substratum. I.O.M.: 22-35 m., in coarse sand and coarse sand with broken shell, few.

Gammarus locusta (L.): typically a marine species occurring on sandy ground beneath stones and among algae usually at low-water mark and in shallow water. Can tolerate some reduction in salinity and normally penetrates for a short distance up estuaries. In certain parts of its range $G$. locusta may live in salinities down to as low as $5-6 \%$. (See Spooner, I947, and Segerstråle, I947.) I.O.M.: intertidal, under stones on sand at low water, P.E. Bay, P.StM. Inner Harbour, Chapel Bay, Poyllvaaish, Castletown Bay, abundant. Offshore: 0-18 m., weed on sand, particularly abundant near water's edge. In the area it is only found in fully marine conditions. Young individuals may occur higher up the shore than the adults.

G. zaddachi Sexton subsp. zaddachi Spooner 1947: inhabits the upper end of estuaries (roughly about the top third of the estuarine zone) and brackish water of low salinities. In some areas can maintain itself under pure fresh-water conditions (Spooner, I947). I.O.M.: occurs only in the Silverburn from the overlap zone with G. $z$. salinus to the upper limit of salt-water penetration, where the water is entirely fresh except for short periods at H.w.S.

G. zaddachi Sexton subsp. salinus Spooner I947: inhabits the middle reaches of stuaries where the salinity fluctuation is greatest; mingling with $G$. locusta at the seaNard end, and with G. z. zaddachi towards the river end. Cannot tolerate fresh water (Spooner, I947). I.O.M. : occurs in all streams which run into the sea over sandy shores, from L.W.N. to about M.T.L. It is absent from streams which run their entire course over rocks and through boulders. Also occurs in the Silverburn in weed and under stones in the stream from the harbour mouth to the limit of high salinity at high tide where it overlaps with $G$. z. salinus.

G. duebeni Lilljeborg: in brackish and fresh water on the upper part of the shore, in estuaries, and in small streams. Under stones, in rock pools, and among algae and fresh-water vegetation. Occurs in water of salinity up to about $2 \mathrm{I} \%$ but usually lower than this value, and is very resistant to unfavourable conditions (Segerstråle, I946). I.O.M. : occurs from H.W.N. to H.W.S. in streams which flow over rock and shingle into the sea, and in brackish pools above high-water mark. It is also found in some small fresh-water streams up to a considerable height above sea-level. These streams are reduced to mere trickles in times of drought. In other larger streams it was not found above high-water mark. Found with $G$. pulex only in the Silverburn. Presumably the animals occurring on the shore belong to Reid's type $\alpha$, while those found in streams are of type $\beta$ (Reid, I939). Localities: Spaldrick, P.E. Bay, Brewery Beach, common.

G. pulex (L.): among vegetation and under stones in fresh-water streams and lakes. Cannot tolerate increased salinity. It is apparently commoner in hard than in soft water. I.O.M.: occurs only in the Silverburn above the tidal zone. 
Marinogammarus marinus (Leach): strictly intertidal, optimum between H.w.N. and M.T.L. Under stones, in fucoids, on gravel, mixed grounds, and soft mud, but absent or scarce on cleaner sands or shingle. Penetrates estuaries for some distance, and can tolerate salinities down to about $10 \%$. I.O.M.: occurs on all rocky shores and is sometimes very abundant. Only found below M.T.L. where there is fresh-water influence. Occurs in streams where it is subject to considerable salinity changes and spends the greater part of each day in water which is entirely fresh. Localities: P.StM. Ledges and Outer Harbour, Spaldrick, Niarbyl, Poyllvaaish, Brewery Beach, Castletown Bay, lower part of Silverburn estuary.

M. obtusatus (Dahl): essentially intertidal, optimum about M.T.L. to L.w.N. Under stones and seaweed. Associated with less muddy and more stony grounds, and capable of existing on comparatively clean pebbles. Penetrates only a short distance into estuaries. Probably cannot tolerate salinities below about $33.5 \%$ except for short periods. I.O.M.: occurs on all rocky shores. Found sparingly in fresh-water streams running over the beach. Intertidal: P.StM. Ledges and Outer Harbour, Spaldrick, Niarbyl, Poyllvaaish, Brewery Beach, Castletown Bay, abundant. Offshore: $9-5 \mathrm{~m}$. in weed on gravel, one.

M. finmarchicus (Dahl): habitat similar to that of $M$. obtusatus but more local and never so abundant. Possibly a tendency to inhabit situations which remain wet at low tide. I.O.M.: Spaldrick, below Biol. Stat., Bradda Head, locally common.

M. stoerensis Reid: strictly intertidal between H.W.N. and L.W.N. where fresh-water streams or seepage flow over the tidal zone. Under flat stones. Penetrating only a short distance into estuaries. Apparently this species can only exist where there are large periodical changes in salinity. I.O.M.: under stones in fresh-water streams, Spaldrick, Brewery Beach, lower part of Silverburn, common.

M. pirloti Sexton \& Spooner: between H.W.N. and L.W.N. on stony beaches where there is fresh-water influence. I.O.M.: occurs in streams running over reefs or pebbles and emptying into the sea over sand. Its optimum zone is from H.W.N. to M.T.L. Occasional specimens may apparently occur away from fresh-water influence, as one individual was obtained from Fucus serratus at L.w.s., in company with Gammarus locusta. Brewery Beach, abundant.

Pectenogammarus planicrurus Reid: the records are too few to formulate a general idea of its habitat, but apparently it is usually intertidal and occurs under boulders (Reid, I944). I.O.M.: under stones between H.w.N. and L.w.N., Spaldrick, few.

\section{DEXAMINIDAE}

Dexamine spinosa (Montagu): among algae at low-water mark and in shallow water. I.O.M.: intertidal, among algae at L.w.S., Chapel Bay and Castletown Bay, few. Offshore: 4-22 m., among weed on sand and gravel, common.

$D$. thea Boeck: among algae. A more pronounced littoral form than D. spinosa but also found in shallow water. I.O.M.: occurs in sheltered situations particularly among Laminaria at L.w.S. Intertidal: P.StM. Outer Harbour, below Biol. Stat., Chapel Bay, Castletown Bay, locally common. Offshore: 7-18 m., weed on sand and gravel, few.

Tritaeta gibbosa (Bate): among algae and associated with sponges usually at lowwater mark but sometimes extending into fairly deep water. I.O.M.: intertidal, in sponges and Laminaria holdfasts at low-water mark, P.StM. Ledges, below Biol. Stat., Chapel Bay, Poyllvaaish, Niarbyl, fairly common. Offshore: $15-60 \mathrm{~m}$., among algae and on sponges, few.

Guernea coalita (Norman): on coarse or mixed grounds in fairly shallow water where it probably lives interstitially. I.O.M.: I I-33 m., in coarse sand and mixed grounds, fairly common. 


\section{TALITRIDAE}

Talitrus saltator (Montagu): burrowing into loose sand and beneath rotting weed on sandy beaches at H.w.S. In the winter months they are found some distance below the surface and possibly hibernate in the manner described for Talorchestia megalophthalma by Edwards \& Irving (I943). I.O.M.: in loose sand at H.w.S., P.E. Bay, abundant.

Orchestia mediterranea A. Costa: usually under stones at about H.W.N. Occupies a zone distinctly below that of O. gammarella, though the two species overlap. Usually found with Marinogammarus marinus. I.O.M.: under stones at H.w.N., Niarbyl, Poyllvaaish, abundant.

O. gammarella (Pallas): usually on rocky shores at and above H.w.s. under stones and among rotting algae. In damp places it may extend considerably above sea-level. I.O.M.: abundant on all shingle beaches beneath rotting weed at H.w.S., P.StM. Outer Harbour, Spaldrick, Poyllvaaish, Niarbyl, Castletown Bay.

Talorchestia deshayesei (Audouin): under rotting weed and stones on sand at H.w.S. I.O.M. : very local and was not collected with Talitrus, although the habitats of the two species are very similar. Castletown Bay, Derby Haven.

Hyale prevosti (Milne-Edwards) $=H$. nilssoni (Rathke): among algae, usually between H.w.N. and L.w.N. Can tolerate fresh water for some time and penetrates estuaries. I.O.M.: occurs on all rocky shores. It lives over most of the tidal zone, being common in Pelvetia at H.W.N. and among algae in pools down to L.W.N. It is found more rarely in Laminaria holdfasts and red algae at L.w.S. and occasionally offshore in a few metres depth. Intertidal: P.StM. Ledges, Spaldrick, below Biol. Stat., Niarbyl, Brewery Beach, Castletown Bay, lower part of Silverburn. Offshore: 9-I5 m., one.

H. pontica (Rathke): among algae near L.w.s., usually in rather exposed situations. I.O.M.: occurs only among algae from L.w.S. and on a floating buoy. Was not found offshore. In one collection it occurred in company with $H$. prevosti at L.W.S. but was considerably more abundant. P.E. Breakwater, fairly common.

\section{AORIDAE}

Aora typica Kröyer: on algae and hydroids in fairly shallow water and occasionally at L.W.S. in sheltered situations. I.O.M.: intertidal in Laminaria holdfasts, P.StM. Outer Harbour, below Biol. Stat., Castletown Bay, few. Offshore: I I-33 m., on algae and hydroids, common.

Microdeutopus damnoniensis (Bate): among algae at low-tide mark and in very shallow water. I.O.M. : on muddy sands at L.W.S., P.StM. Inner Harbour, and Chapel Bay, few.

Lembos websteri Bate: at L.w.s. and in shallow water on algae, particularly in the holdfasts of Laminaria digitata. I.O.M. : intertidal, abundant everywhere in Laminaria holdfasts, P.StM. Ledges and Outer Harbour, below Biol. Stat., Chapel Bay, Poyllvaaish, Castletown Bay, Niarbyl. Offshore: 7-22 m., on algae, few.

L. longipes (Lilljeborg): burrowing in coarse to muddy sand in moderate depths. I.O.M. : $29-82 \mathrm{~m}$., in coarse and muddy sand, fairly common.

\section{Photidae}

Microprotopus maculatus Norman: always associated with a sandy bottom in shallow water. May sometimes burrow into the deposit but its usual habitat is among loose algae. I.O.M. : 2-I8 m., in weed on sand, common.

Photis longicaudata (Bate \& Westwood): probably burrows in fine to muddy sand or mixed grounds in moderate depths. I.O.M.: $27-82 \mathrm{~m}$., on mixed grounds, few.

Eurystheus melanops (G. O. Sars): probably on mixed grounds in moderately deep water. I.O.M.: I I-33 m., mixed grounds, few. This species has not previously been 
recorded with certainty from the British Isles as there has been some confusion with E. erythrophthalmus. It is much scarcer than the next species.

E. erythrophthalmus (Lilljeborg) $=E$. maculatus (Johnston): usually on hydroids in moderate depths and on algae in shallow water. Between tide-marks it seems to be almost confined to the holdfasts of Laminaria digitata, of which it is a typical and sometimes abundant inhabitant. I.O.M.: intertidal, in Laminaria at low-water mark, P.StM. Ledges, below Biol. Stat., Poyllvaaish, Castletown Bay, Niarbyl, common. Offshore: 2-82 m., mainly on hydroids and algae, common.

E. palmatus (Stebbing \& Robertson): on hydroids and muddy or mixed grounds in fairly deep water. I.O.M.: $29-60 \mathrm{~m}$., on hydroids and mixed grounds, few.

Podoceropsis nitida Stimpson: in moderately deep water on hydroids or commensal in the shells inhabited by hermit crabs. I.O.M.: II-60 m., in shells of Buccinum inhabited by Eupagurus bernhardus and on hydroids, common.

Megamphopus cornutus Norman: in mixed grounds usually in fairly shallow water. I.O.M. : 7-33 m., on mixed grounds, fairly common.

Protomedeia fasciata Kröyer: in muddy sand at moderate depths. I.O.M.: 73 m., muddy sand, few. Not previously obtained so far south.

Leptocheirus hirsutimanus Bate: probably in rather coarse or mixed grounds in moderate depths. I.O.M.: 33 m., mixed grounds, few.

L. pectinatus Norman: in fine gravel or mixed grounds, usually in fairly shallow water. I.O.M.: 9-36 m., in gravel and mixed grounds, common.

\section{ISAEIDAE}

Isaea montagui Milne-Edwards: only found on the mouthparts of Maia squinado. I.O.M.: on Maia, Langness Point, few.

\section{AMPHITHOIDAE}

Amphithoë rubricata (Montagu): on the shore or in shallow water on algae or under stones. Occurs in pools and among algae from M.T.L. downwards, and is particularly abundant in the holdfasts of Laminaria digitata. I.O.M.: intertidal, under stones and in Laminaria holdfasts, P.StM. Ledges and Outer Harbour, below Biol. Stat., Chapel Bay, Poyllvaaish, Castletown Bay, common. Offshore: 7-18 m., on algae, few.

Pleonexes gammaroides Bate: habitat similar to that of Amphithoë rubricata but favours more exposed positions. I.O.M.: intertidal, among algae at L.w.S., P.StM. Ledges, Chapel Bay, P.E. Breakwater, few. Offshore: 7-15 m., on algae, one.

Sunamphithoë pelagica (Milne-Edwards): usually on algae in shallow water. I.O.M.: intertidal, on Fucus at L.w.s., P.StM. Inner Harbour, one. Offshore: 4-9 m., on algae, one.

Biancolina cuniculus (Stebbing): probably among algae in very shallow water. I.O.M.: on red algae at extreme L.w.S., Chapel Bay, one. Not previously recorded farther north than Devon. Apparently very rare.

\section{JASSIDAE}

Fassa falcata (Montagu) incl. F. dentex (Czerniavski), Chevreux \& Fage (I925, p. 348): among algae at low-water mark and in very shallow water. Particularly abundant and grows to a large size among the algae on floating buoys. The younger forms are sometimes found in sponges. On the authority of Mrs E. W. Sexton (in litt.) I have included the form described by Chevreux \& Fage as $\mathcal{F}$. dentex (Czerniavski) in the species F. falcata (Montagu). Both forms of the male are common in the area and sometimes occur together. This was noted by Walker (I9II). I.O.M. : intertidal, in Laminaria holdfasts and occasionally on sponges at L.w.S., P.StM. Ledges and Outer Harbour, 
below Biol. Stat., P.E. Breakwater and buoy, Poyllvaaish, Castletown Bay, Niarbyl, common. Offshore: 2-15 m., on algae, few.

F. pusilla (G. O. Sars): on hydroids and among sponges on Inachus dorsettensis in moderately deep to deep water. Apparently never in very shallow water. I.O.M. : 27-33 m., on Inachus, common.

F. ocia (Bate): among algae and particularly in sponges from M.T.L. to L.w.S. I.O.M.: in sponges and Laminaria holdfasts on the shore from M.T.L. downwards, P.StM. Ledges, below Biol. Stat., Poyllvaaish, Castletown Bay, fairly common.

Parajassa pelagica (Leach): habitat similar to that of fassa falcata but generally scarcer. I.O.M.: among algae at L.w.S., P.StM. Ledges, P.E. Breakwater and buoy, Poyllvaaish, Niarbyl, few.

Microjassa cumbrensis (Stebbing \& Robertson): mainly on mixed grounds in moderately deep water. It may live interstitially or on hydroids. I.O.M. : I I-64 m., on mixed grounds and hydroids, fairly common.

\section{COROPHIIDAE}

Ericthonius brasiliensis (Dana): on algae at L.w.s. in sheltered situations and extending into deeper water on hydroids. I.O.M.: intertidal, in Laminaria holdfasts, P.StM. Inner and Outer Harbours, Poyllvaaish, few. Offshore : I-82 m., on algae and hydroids, fairly common.

Unciola planipes Norman: probably burrowing in coarse sand or mixed grounds, usually in fairly deep water. I.O.M.: $35 \mathrm{~m}$., in coarse sand, few.

Siphonoecetes dellavallei Stebbing: on fine sand in shallow water living in tubes constructed of sand grains and fine gravel usually attached to small pieces of shell. I.O.M. : 2-I8 m., on fine sand, common.

Corophium volutator (Pallas): burrowing in muddy sand in sheltered places between tide-marks on the shore, but usually in estuaries. It is found in varying salinity conditions from about I to $34 \%$. The controlling factor in its distribution is probably the presence or absence of a suitable soil which depends largely on the amount of shelter from winds and currents (Hart, I930; Beanland, I940). I.O.M.: in muddy sand from H.W.N. to M.T.L., P.StM. Inner Harbour and Silverburn Estuary, abundant. The species seems to be absent or very scarce in P.StM. Inner Harbour during the early part of the year. At least it could not be found there at the end of March I946, but was abundant a month later, and the population then included many large ovigerous females. It is possible that in this locality it is a summer visitor (see Beanland, I940).

C. affine Bruzelius: burrowing in muddy sand, usually in moderately deep water. I.O.M.: 59 m., muddy sand, fairly common.

C. crassicorne Bruzelius: burrowing in muddy sand in shallow water and at L.W.S. in sheltered situations. I.O.M.: in muddy sand at E.L.W.S., P.StM. Outer Harbour, few.

C. bonelli (Milne-Edwards): in tubes on algae and hydroids at L.w.s. and in fairly shallow water. I.O.M.: intertidal, in Laminaria holdfasts and on sponges, P.StM. Outer Harbour, below Biol. Stat., Chapel Bay, Poyllvaaish, Niarbyl, few. Offshore: I I-27 m., on algae and hydroids, few.

\section{Cheluridae}

Chelura terebrans Philippi: bores in wooden piles, etc., and in submerged driftwood in shallow water. I.O.M.: in submerged wood, $18 \mathrm{~m}$., abundant.

\section{PODOCERIDAE}

Dulichia porrecta (Bate): in moderately deep water. The type of ground that it usually inhabits is difficult to estimate from the records. It may be often associated with Pecten maximus on mixed grounds. I.O.M.: 29 m., on muddy sand with broken shell, one. 


\section{CAPRELlidAe}

\section{Caprellidea}

Phtisica marina Slabber: usually on algae or hydroids from L.w.s. to fairly deep water. I.O.M.: intertidal, in mud in deep clefts at L.w.S., P.StM. Ledges, few. Offshore: 2-82 m., on algae, hydroids, and mixed grounds, common.

Pseudoprotella phasma (Montagu): on algae and hydroids at L.W.M. and in fairly shallow water, sometimes descending to greater depths. I.O.M.: 7-33 m., on algae and hydroids, common. It is particularly common on Obelia growing on the fronds of Laminaria.

Podalirius typicus Kröyer=Pariambus typicus (Kröyer): usually in fairly shallow water on fine sand or in the ambulacral grooves of Asterias or Solaster. I.O.M.: intertidal, muddy sand at L.w.S., P.StM. Outer Harbour, one. Offshore: 4-29 m., mainly on fine sand, fairly common.

Parvipalpus capillaceus (Chevreux): habitat impossible to estimate. I.O.M.: 29 m., muddy sand with broken shell, one. Apparently a very rare species, being known previously only from the west coast of France and Valencia Harbour, Eire.

Caprella acanthifera Leach: from L.w.N. to shallow water offshore, mainly on algae and sponges, seldom on hydroids. I.O.M. : intertidal, in Laminaria holdfasts and on sponges under stones from L.w.N. downwards, P.StM. Ledges and Outer Harbour, Chapel Bay, Castletown Bay, Niarbyl, few. Abundant at Poyllvaaish. Offshore: 4-29 m., on algae, common.

C. acutifrons Latreille: on floating wreckage, buoys, and breakwater. In deep water on sponges and hydroids. Sometimes associated with tunicates (Harrison, I944). I.O.M. : on red algae at L.W.S., P.E. Breakwater, common.

C. linearis (L.): on hydroids and floating wreckage, buoys, etc. Usually below lowwater mark but intertidally in suitable localities. I.O.M.: intertidal, on red algae at L.w.S., P.E. Breakwater, few. Offshore: II-37 m., on hydroids and algae, locally common.

C. fretensis Stebbing: probably on algae and hydroids in fairly shallow water. I.O.M.: intertidal, on red algae at L.W.S., P.E. Breakwater, one. Offshore: I I-I8 m., on algae, one. Previously known only from the Channel and farther south.

\section{HYPERIIDAE}

\section{Hyperiidea}

Hyperia galba (Montagu): at or near the surface, usually commensal with Scyphomedusae. I.O.M.: commensal with Rhizostoma, common.

Themisto abyssorum (Boeck) = Parathemisto oblivia (Kröyer): pelagic usually in deep water, sometimes near surface. I.O.M.: $82 \mathrm{~m}$., in young fish trawl, one.

\section{Discussion}

\section{Economic Importance}

The most striking fact that emerges from intensive collecting of amphipods is that of their general abundance. On the shore species of Marinogammarus or Bathyporeia, on rocky or sandy facies respectively, are often present in large numbers and sometimes extremely plentiful. Near low-water mark a variety of species are very common among algae. It is, however, in moderate depths that the group reaches its maximum importance. In shallow water it is no uncommon occurrence to obtain several hundred individuals in a short haul. 
Table I. The Distribution of the Offshore Species

(The figures opposite each species give the total number captured on each type of ground or habitat)

\begin{tabular}{|c|c|c|c|c|c|c|c|c|c|c|c|}
\hline Гype of ground or habitat... & 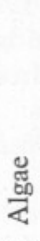 & 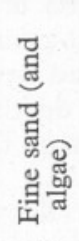 & 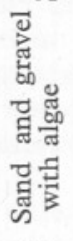 & 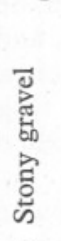 & 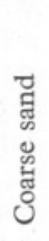 & 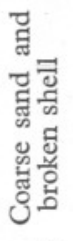 & $\begin{array}{l}\stackrel{0}{0} \\
\stackrel{0}{0} \\
\text { 吾 }\end{array}$ & 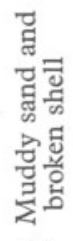 & 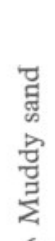 & $\sum_{\bar{u}}^{J}$ & $\begin{array}{l}\text { 品 } \\
\text { Бे } \\
\text { के }\end{array}$ \\
\hline Number of hauls $\quad \ldots$ & Io & 12 & II & 4 & 3 & 12 & II & I7 & 6 & 3 & 2 \\
\hline $\begin{array}{l}\text { ysianassidae: } \\
\text { Acidostoma obesum }\end{array}$ & - & & & - & - & - & - & - & I & 工 & - \\
\hline 年 & 一 & & & & - & & I & - & - & - & - \\
\hline $\mathrm{Na}$ & - & - & 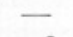 & - & - & - & I & - & - & - & - \\
\hline & - & & 3 & - & & & 3 & I6 & I & - & - \\
\hline rella audouiniana & - & 二 & & - & & & 2 & $\pi$ & - & - & 25 \\
\hline mene humilis & 2 & - & & - & & - & 8 & - & 二 & 二 & \\
\hline $\begin{array}{l}\text { Socarnes erythrophthalmu } \\
\text { Hippomedon denticulatus }\end{array}$ & - & 3 & 296 & 93 & I & & 二 & - & - & 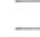 & \\
\hline Scopelocheir & - & - & - & - & 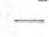 & I & I & 3 & 6 & & \\
\hline & - & 3 & - & - & - & - & - & - & - & - & - \\
\hline $\begin{array}{l}\text { Tmetor } \\
\text { Orchon }\end{array}$ & - & -2 & & - & & $I$ & - & - & - & - & \\
\hline lella nana & & & & & & 1 & - & & 一 & - & \\
\hline evicornis & - & 9 & 2 & - & - & - & - & - & - & - & 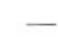 \\
\hline & & & & 1 & & & & I? & & & \\
\hline & $-1+2>$ & - & & - & & & I & $3 \mathrm{I}$ & 8 & & \\
\hline & & & & 2 & & $=$ & 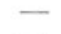 & $=$ & I & & \\
\hline A, tenuicornis & - & & & & & & & & & & \\
\hline
\end{tabular}

Argissidae:

Argissa hamatipes

Haustoriidae:

Bathyporeia guilliamsoniana

$B$. elegans

B. gracilis

Urothoë elegans

U. marina

Phoxocephalidae:

Paraphoxus oculatus

Metaphoxus fultoni

Harpinia antennaria

$H$. pectinata

$H$. crenulata

Amphilochidae:

Amphilochus manudens

A. spence-batei

Amphilochoides serratipes

Peltocoxa brevirostris

Gitana sarsi

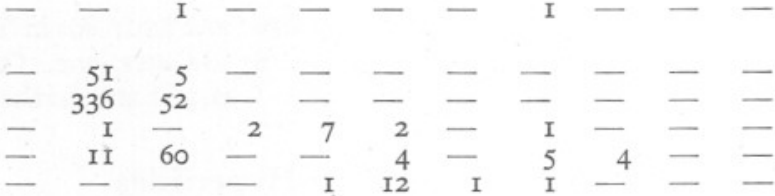

Leucothoidae:

Leucothoë spinicarpa

L. lilljeborgi

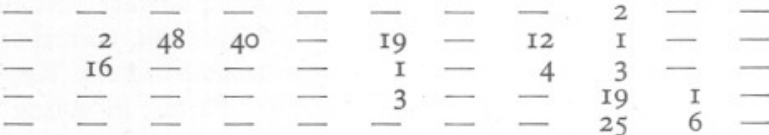

Stenothoidae:

Metopa bruzelii

M. pusilla

M. borealis

Stenothoë monoculoides

S. marina

$S$. antennulariae

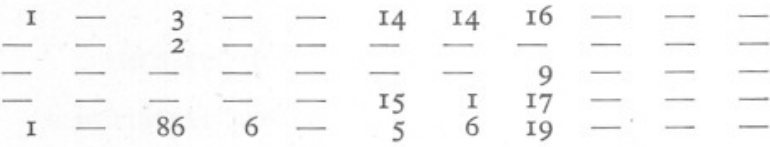

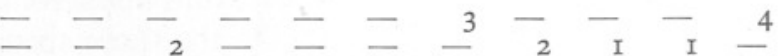

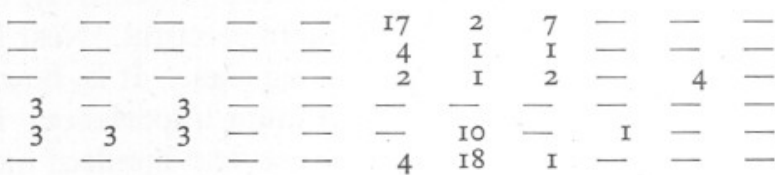


Table I (cont.)

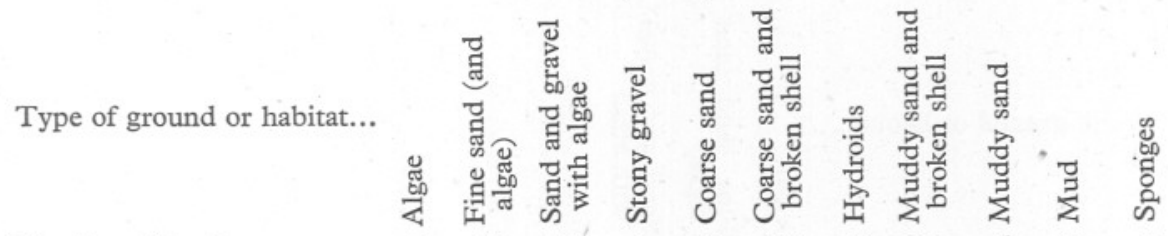

$\begin{array}{llllllllllllll}\text { Number of hauls } & \ldots & \ldots & \text { IO } & \text { I2 } & \text { II } & 4 & 3 & \text { I2 } & \text { II } & \text { I7 } & 6 & 3 & 2\end{array}$

Cressidae:

Cressa dubia

Colomastigidae:

Colomastix pusilla

Acanthonotozomatidae:

Panoploea minuta

P. eblanae

Iphimedia obesa

Lilljeborgiidae:

Lilljeborgia brevicornis

L. kinahani

Oedicerotidae:

Perioculodes longimanus

Pontocrates arenarius

$P$. norvegicus

Synchelidium haplocheles

Monoculodes carinatus

M. subnudus

Westwoodilla caecula

Tironidae:

Syrrhoites fimbriatus

Calliopiidae:

Apherusa bispinosa A. jurinei

Pleustidae:

Parapleustes monocuspis Stenopleustes nodifer

Paramphithoidae: Epimeria cornigera

Atylidae:

Nototropis swammerdami

$N$. vedlomensis

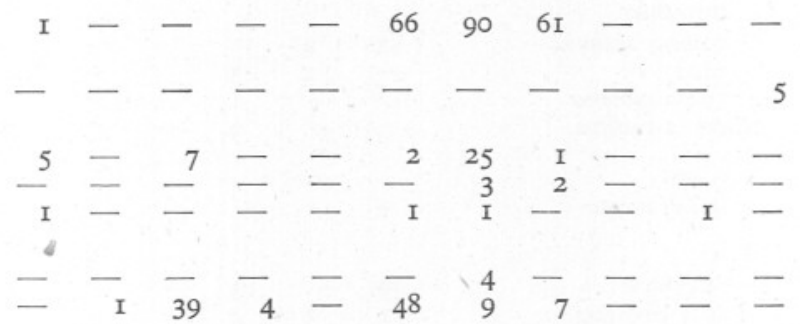

Melphidippidae:

Melphidippella macra

Eusiridae:

Eusirus longipes

Gammaridae:

Gammarellus homari

Cheirocratus sundevalli

C. assimilis

Megaluropus agilis

Melita hergensis

M. obtusata

Ceradocus semiserratus

Maera othonis

Maerella tenuimana

Gammarus locusta

$\begin{array}{rrrrrrrrrrr}\text { I } & 40 & 22 & - & - & - & - & - & 9 & 7 & - \\ - & 26 & - & - & - & - & - & - & - & - & - \\ 2 & 103 & 14 & - & - & - & - & - & - & - & - \\ - & \text { I0 } & 28 & 3 & \text { I } & \text { I6 } & 2 & 25 & - & - & - \\ - & - & 4 & - & - & 4 & - & 6 & - & - & - \\ - & -1 & 2 & - & - & \text { I } & - & 7 & - & - & - \\ - & - & - & - & - & - & - & - & - & 53 & -\end{array}$

Marinogammarus obtusatus

$\begin{array}{rrrrrrrrrr}31 & 30 & 263 & 2 & - & - & 2 & 4 & 3 & -\end{array}-$

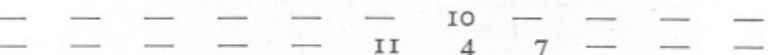

- - - - -

$\begin{array}{lllllllllll}56 & 4 & - & - & - & - & - & - & - & - & -\end{array}$

- 13 - 3 - $\begin{array}{lllllll}6 & 3 & 36 & 3\end{array}-$

- - I - I $-\begin{array}{lllllll} & \text { I6 } & 4 & 6 & \text { I } & -\end{array}$

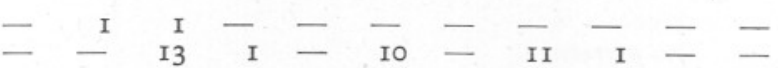

- $-\frac{13}{9}-\frac{1}{-}-5-2^{1}-$

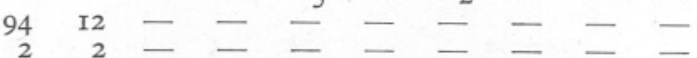

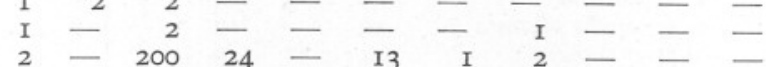

$\begin{array}{rrrrrrrrrrr}2 & - & 200 & 24 & - & { }^{13} & \text { I } & 2 & - & - & - \\ -1 & 2 & 13 & 3 & - & 58 & \text { I7 } & 3^{8} & 2 & - & - \\ \mathrm{I} & -8 & -8 & - & 4 & 4 & - & - & - & - & -\end{array}$ 


\section{Table I (cont.)}

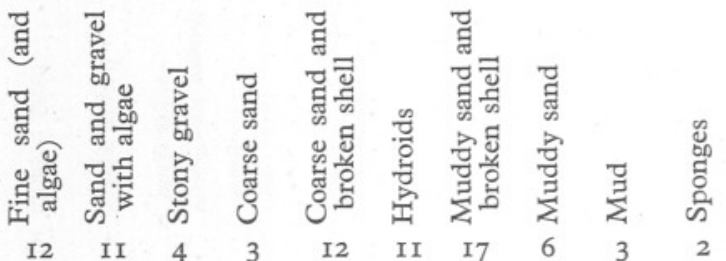

Number of hauls

IO I2 II 4

Dexaminidae:

Dexamine spinosa

D. thea

Tritaeta gibbosa

Guernea coalita

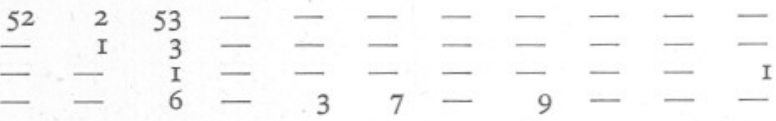

Talitridae:

Hyale prevosti

Aoridae:

Aora typica

Lembos websteri

L. longipes

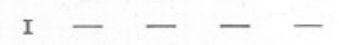

$\begin{array}{rrrrrrrrrrr}39 & - & \text { I3 } & - & - & \text { I } & 30 & \text { I } & - & - & - \\ 22 & 3 & 2 & - & - & - & - & - & - & - & -\end{array}$

Photidae:

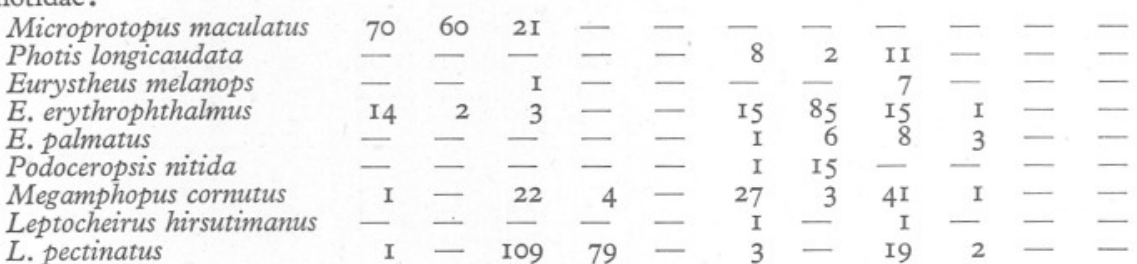

Amphithoidae:

Amphithoë rubricata

Pleonexes gammaroides

Sunamphithoë pelagica

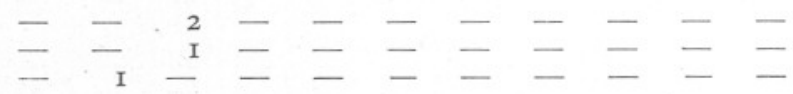

Jassidae:

fassa falcata

$\mathcal{F}$. pusilla

Microjassa cumbrensis

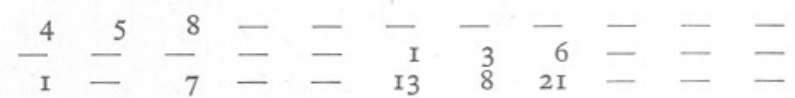

Corophiidae:

Ericthonius brasiliensis

Unciola planipes

Siphonoecetes dellavallei

Corophium affine

C. bonelli

Podoceridae:

Dulichia porrecta

Caprellidae:

Phtisica marina

Pseudoprotella phasma

Podalirius typicus

Parvipalpus capillaceus

Caprella acanthifera

C. linearis

C. fretensis

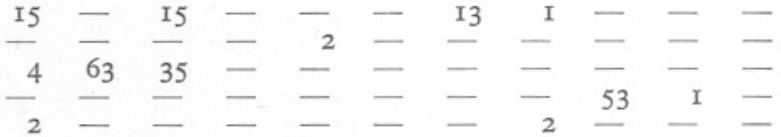

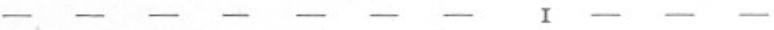

\begin{tabular}{rrrrrrrrrrr}
28 & 4 & II 4 & 3 & - & IO & 69 & II & I6 & - & - \\
40 & - & I2 & - & - & - & 2 & - & - & - & - \\
I & 35 & 9 & - & - & - & - & I & - & - & - \\
\hline & - & - & - & - & - & - & I & - & - & - \\
$4 \mathrm{I}$ & 9 & 9 & 2 & - & - & - & I & - & - & - \\
2 & 2 & - & - & - & - & 6 & - & - & - & - \\
2 & - & - & - & - & - & - & - & - & - & -
\end{tabular} 
The number of species obtained is often great, and in haul no. 70, taken with a tow-net attached to the otter trawl, there were over 325 individuals belonging to thirty-three separate species; while on several occasions a haul of the small fine-meshed dredge, which was towed only a few yards, brought up over Ioo individuals belonging to more than twenty species. As a rule two or three species are predominant and make up the greater part of the catch, but the majority are widely distributed on the kind of bottom that they favour. I have found the Amphipoda to be a dominant group, in numbers if not in bulk, on all types of offshore ground that I have investigated. It is therefore possible that they are of even greater economic importance than has been realized. They have been shown to be an important source of food for fish, especially young fish, and they are probably largely eaten by other animals upon which fish feed (see Hunt, 1925, and Steven, I930).

\section{Habitats of Offshore Species}

I have compiled lists of the species which I consider to be significant for various habitats. These lists are obtained by finding the average number of individuals per haul of each species on the different grounds. They are not of equal value for each habitat, as the number of hauls taken varied from only three on a mud bottom to seventeen on a bottom of muddy sand with broken shell. The hauls also varied in distance covered and were taken with a variety of gear. The lists do not, therefore, provide any information as to the absolute density of population but they are an attempt at classification into habitat groups with an observed numerical basis, however imperfect.

In assessing the significance of any species on a particular ground I have included it where it has an average value per haul of 0.8 or more. This is an arbitrary figure which may be considered low, but the area covered by any one haul is usually small and when the species may be present in an average of eight hauls out of ten the total population on the ground is probably large. The average occurrence in hauls is not necessarily related to the average number of individuals per haul as the latter is sometimes brought up by large numbers in one or two hauls only, but on the whole the spreadover is fairly even and I have not thought it practical to discriminate between these two values. Habitat (I) consisted of weed, often lying loose on the bottom, mainly brought up in the otter trawl. Habitat (2) was to some extent mixed, as a certain amount of loose weed was present. Habitat (3) included parts of (I), (2) and (4). Habitat (7) consisted of hydroids and polyzoans usually attached to shells and stones on mixed grounds. Where the habitat is a combination of two or more of the others listed, that to which each species should properly be referred is indicated by the number set in heavier type following the name of the species. After the name of the species are also indicated (in brackets) the other habitats for which it was significant. 


\section{SPECIES WHICH ARE PROBABLY SIGNIFICANT FOR VARIOUS HabITATS}

(I) Weed, including loose weed, on fine sand. Depth 4-22 m.

Apherusa bispinosa

Nototropis swammerdami

Eurystheus erythrophthalmus $(6,7,8)$

Dexamine spinosa

Aora typica (7)

Lembos websteri

Microprotopus maculatus (2)

Ericthonius brasiliensis (7)

Phtisica marina $(6,7,9)$

Pseudoprotella phasma

Caprella acanthifera

(2) Fine sand (with some loose weed). Depth 2-I2 m.

Socarnes erythrophthalmus (4)

Bathyporeia guilliamsoniana

B. elegans

Urothoë elegans (9)

Stenothoë marina $(\mathbf{I}, 7)$

Perioculodes longimanus (9, 10)

Pontocrates arenarius
Pontocrates norvegicus

Synchelidium haplocheles $(6,8)$

Apherusa bispinosa (I)

Megaluropus agilis

Microprotopus maculatus (I)

Siphonoecetes dellavallei

Podalirius typicus

(3) Sand and fine gravel (with some weed). Depth I I-I $8 \mathrm{~m}$.

Socarnes erythrophthalmus (2, 4)

Bathyporeia elegans (2)

Urothoë elegans (2)

Metaphoxus fultoni (4)

Gitana sarsi (4)

Lilljeborgia kinahani (4)

Perioculodes longimanus (2)

Pontocrates norvegicus (2)

Synchelidium haplocheles (2)

Apherusa bispinosa (I)

Nototropis vedlomensis (4)

Cheirocratus sundevalli (6)

Megaluropus agilis (2)
Ceradocus semiserratus (4)

Maera othonis $(6,7,8)$

Dexamine spinosa (I)

Aora typica (I)

Microprotopus maculatus (I)

Megamphopus cornutus (4)

Leptocheirus pectinatus (4)

Ericthonius brasiliensis (I)

Siphonoecetes dellavallei (2)

Phtisica marina (I)

Pseudoprotella phasma (I)

Podalirius typicus (2)

Caprella acanthifera (I)

(4) Stony gravel. Depth $\mathrm{r} 8-35 \mathrm{~m}$.

Socarnes erythrophthalmus (2)

Nototropis vedlomensis $(6,8)$

Metaphoxus fultoni (6)

Ceradocus semiserratus (6)

Gitana sarsi (8)

Lilljeborgia kinahani $(6,7)$

Megamphopus cornutus $(6,8)$

Leptocheirus pectinatus (8)

(5) Coarse sand. Depth $18-35 \mathrm{~m}$.

Bathyporeia gracilis

Guernea coalita

Maerella tenuimana

Lembos longipes (9)

(6) Coarse sand with broken shell. Depth I8-55 m.

Lysianassa plumosa (8)

Orchomenella nana

Urothoë marina

Metaphoxus fultoni (4)

Amphilochus manudens $(7,8)$
Peltocoxa brevirostris (8)

Metopa bruzelii

Cressa dubia $(7,8)$

Lilljeborgia kinahani $(4,7)$

Synchelidium haplocheles $(2,8)$ 
Stenopleustes nodifer

Nototropis vedlomensis $(4,8)$

Melphidippella macra (8)

Eusirus longipes

Cheirocratus sundevalli (3)
Maera othonis $(3,7,8)$

Eurystheus erythrophthalmus ( 1,7$)$

Megamphopus cornutus $(4,8)$

Microjassa cumbrensis (8)

Phtisica marina $(1,7,8)$

(7) Hydroids and polyzoans, mainly on mixed grounds. Depth $20-82 \mathrm{~m}$.

Amphilochus manudens $(6,8)$

Stenothoë marina

S. antennulariae

Cressa dubia $(6,8)$

Panoploea minuta

Lilljeborgia kinahani $(4,6)$

Parapleustes monocuspis
Maera othonis $(3,6,8)$

Aora typica (I)

Eurystheus erythrophthalmus (I, 6)

Ericthonius brasiliensis (I)

Phtisica marina $(\mathrm{I}, 6,8)$

Caprella linearis

(8) Muddy sand with broken shell. Depth 27-38 m.

Lysianassa plumosa (6)

Ampelisca spinipes (9)

A. diadema (9)

A. tenuicornis (9)

Amphilochus manudens $(6,7)$

Peltocoxa brevirostris (6)

Gitana sarsi (4)

Cressa dubia $(6,7)$
Synchelidium haplocheles $(2,6)$

Nototropis vedlomensis $(4,6)$

Melphidippella macra (6)

Maera othonis $(3,6,7)$

Eurystheus erythrophthalmus (I, 6, 7)

Megamphopus cornutus $(4,6)$

Leptocheirus pectinatus (4)

Microjassa cumbrensis (6)

(9) Muddy sand. Depth 3I-82 m.

Scopelocheirus crenatus

Ampelisca spinipes (8)

A. diadema (8)

A. tenuicornis (8)

Urothoë elegans (2)

Harpinia pectinata
Harpinia crenulata (Io)

Perioculodes longimanus (2, 9)

Lembos longipes (6)

Corophium affine

Phtisica marina $(\mathrm{I}, 6,8)$

(10) Mud. Depth $82-88 \mathrm{~m}$.

Harpinia crenulata (9)

Metopa borealis

Perioculodes longimanus (2, 9)

Westwoodilla caecula

(II) Sponges, growing on a bed of Modiolus. Depth $60 \mathrm{~m}$.

Perrierella audouiniana

Leucothoë spinicarpa
Colomastix pusilla

Tritaeta gibbosa

(I2) Specialized habitats

Laphystius sturionis, parasitic on fish

Melita obtusata, on Asterias and Luidia

Podoceropsis nitida, in hermit crab shells

fassa pusilla, in sponges on Inachus

Chelura terebrans, in submerged wood 
The habitats shown include all those that have been found offshore in the area. It will be seen that many species are common to two or more habitats or grounds, while some are confined to one, but where a species occurs on several grounds these have as a rule some common feature. Thus stony gravel and mixed grounds may be grouped together as containing coarse deposits. Some species which occur on algae also occur on hydroids. On the whole, in fact, the Amphipoda are quite selective with regard to the type of ground on which they live.

Certain closely related species occupy very different habitats in the same area. Leucothoë spinicarpa is associated, probably as a commensal, with sponges and ascidians, while $L$. lilljeborgi burrows in silty ground; Nototropis swammerdami lives on sublittoral algae while $N$. vedlomensis is found in mixed grounds and gravels; Lembos websteri occurs on algae mainly at low water while L. longipes probably burrows in various grades of sand in at least some metres depth. Differences in habitat of this description are not always so clear but in other genera a trend from one grade of deposit to another can be seen over a series of species as in the example of Ampelisca and Harpinia set out below. A similar trend may be observed among the closely related genera of the Oedicerotidae.

From the information so far obtained as to the distribution of the Amphipoda on various grounds some idea may be gained of the place of a number of species in the general schema of animal communities in the sea. In this matter I shall refer to the system used by Ford (I923). He divided the infaunal communities on the sea-bottom near Plymouth into two main series, the Echinocardium cordatum-Venus gallina $(E c-V g)$ community characteristic of finer soils, and the Spatangus purpureus-Venus fasciata $(S p-V f)$ community characteristic of coarser grades. The $E c-V g$ series was divided into four subgroups, (I) being characteristic of clean sand, (2) and (3) of silty sand, and (4) of black mud. The communities in the neighbourhood of Port Erin fall within the limits of this system.

In the table below (Table II) certain species of Amphipoda from the area are referred to this system. As there is no rigid boundary between one community and another it is usually only possible to indicate a preference for one grade of deposit. An arrow-head opposite a specific name shows a tendency for that species to be found in mixed communities corresponding to a mixture of coarse and fine grades of deposit, or to occur in more than one grade. No species by itself could be used to diagnose the community in which it occurred, but a number of species together would provide a fairly sound indication of the other animals to be expected on the same ground. 
Table II. Habitat Distribution of OfFshore Amphipoda

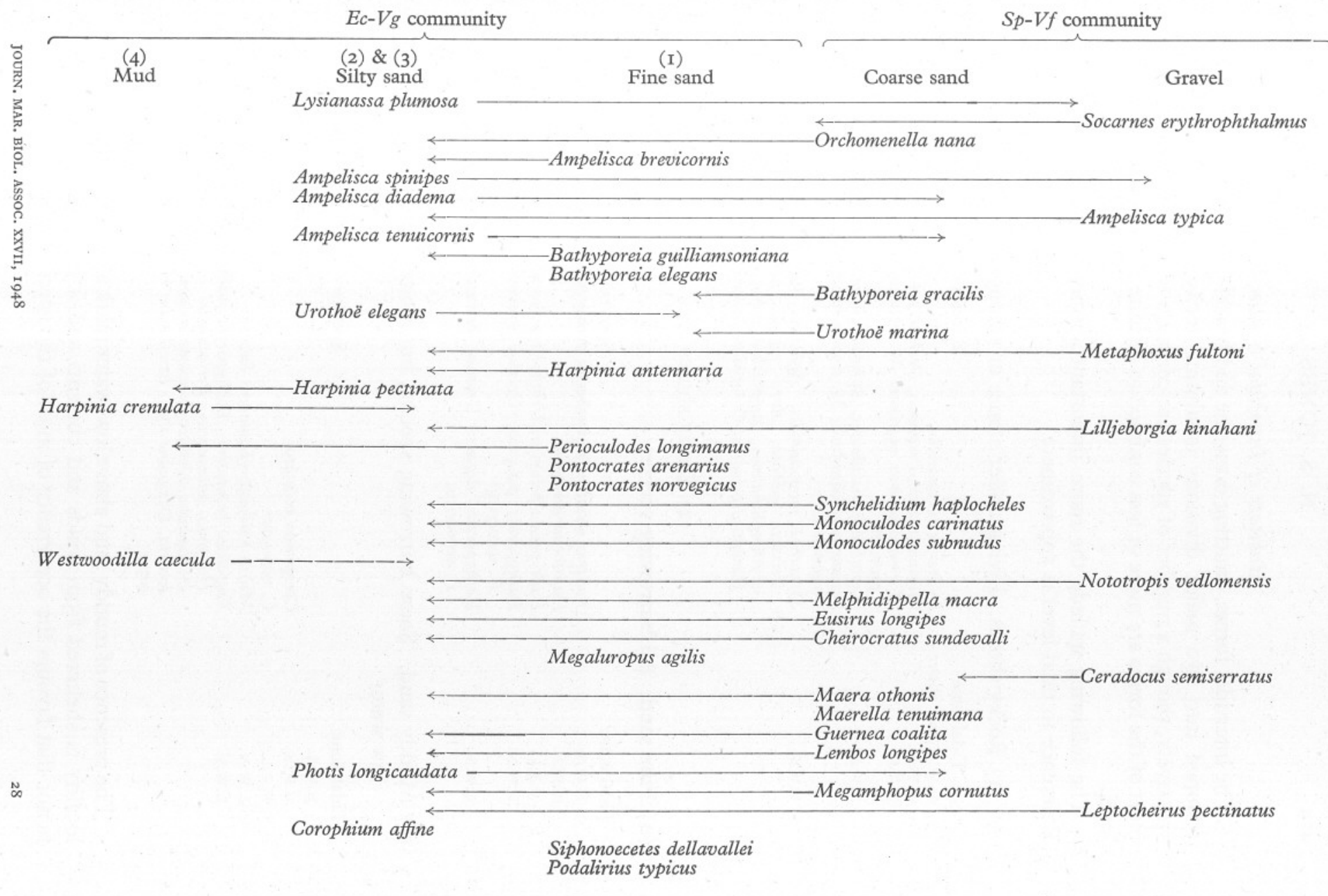




\section{Habitats of Intertidal Species}

The intertidal forms, omitting estuarine and brackish-water species, may be grouped into two major divisions inhabiting rocky and sandy shores respectively, though a number of species are common to both. In each division most of the forms are more or less confined to definite zones in relation to tidal level.

The following include the more important species occurring in the area. Reference to tidal level is approximate.

(I) Rocky shores. Living under stones or among algae and in pools

Tidal zone H.w.S. and above H.W.N. M.T.L.

L.W.N

L.W.S.

\section{Species}

Orchestia gammarella

Marinogammarus marinus, Orchestia mediterranea, Hyale prevosti Marinogammarus marinus, $M$. obtusatus, $M$. finmarchicus, Hyale prevosti

Stenothoë monoculoides, Apherusa jurinei, Melita palmata, Marinogammarus obtusatus, M. finmarchicus, Hyale prevosti, Amphithoë rubricata

Stenothoë monoculoides, Apherusa jurinei, Gammarellus homari, Tritaeta gibbosa, Aora typica, Lembos websteri, Eurystheus erythrophthalmus, Amphithoë rubricata, fassa falcata, $\mathcal{F}$. ocia, Parajassa pelagica, Corophium bonelli, Caprella acanthifera

\section{(2) Sandy shores}

(a) Fine sand. All burrowing species

Tidal zone

H.W,S.

H.W.N.

M.T.L.

L.W.N.

L.W.S.

\section{Species}

Talitrus saltator, Talorchestia deshayesei

Haustorius arenarius

Bathyporeia pelagica, Urothoë brevicornis, Pontocrates arenarius

Bathyporeia pelagica, Urothoë brevicornis, Pontocrates arenarius, $P$. norvegicus

Bathyporeia elegans, Urothoë brevicornis, Pontocrates arenarius,

(b) Muddy sand. Some burrowing species, but many found among algae at low water

Tidal zone

H.w.s.

H.W.N.

M.T.L.

L.W.N.

L.W.S.

\section{Species}

Corophium volutator

C. volutator

Melita palmata, Gammarus locusta

Ampelisca brevicornis, Bathyporeia guilliamsoniana, Urothoë elegans, Harpinia antennaria, Perioculodes longimanus, Apherusa cirrus, A. bispinosa, Nototropis swammerdami, Melita hergensis, Gammarus locusta, Dexamine thea, Ericthonius brasiliensis, Corophium crassicorne

The presence of muddy sand above low-water mark always indicates that the locality is sheltered from winds and currents and it is probably the shelter factor that favours the occurrence of most of the species in list $(2 b)$. 
List (2a) was mainly compiled from collections made on the fine sand of Port Erin Bay. It may be compared with the data given for Kames Bay, Millport, by Watkin (I94I), which may be set out as follows:

\footnotetext{
Tidal zone

H.W.S.

H.W.N.

M.T.L.

L.W.N.

L.W.S.
}

\section{Species}

Bathyporeia pilosa, Haustorius arenarius

Bathyporeia pelagica, Urothoë brevicornis, Pontocrates norvegicus

Bathyporeia pelagica, B. elegans, Urothoë brevicornis, Pontocrates arenarius, $P$. norvegicus

Bathyporeia guilliamsoniana, B. elegans, Urothoë brevicornis, Pontocrates arenarius, $P$. norvegicus

As Watkin was not concerned with the Talitridae it is evident that on the whole the two beaches show a similar amphipod fauna and zonation. The most striking difference is that Bathyporeia pilosa is present abundantly at Kames Bay but is absent from Port Erin Bay. This may be due to the absence of suitable ground about H.W.N. at Port Erin. The species probably occurs on the sandy shores at the north end of the Isle of Man, since it has been recorded from Millport and from the west coast of Wales. The density of population is generally lower at Port Erin than at Millport.

Colman (1940) investigated the faunas of intertidal seaweeds including Laminaria digitata holdfasts. It is interesting to compare the results for Plymouth and the Isle of Man for the latter habitat.

\section{AMPHIPODA FROM LAMINARIA HOLDFASTS}

Plymouth

Stenothoë monoculoides

Apherusa jurinei

Tritaeta gibbosa

Lembos websteri

Eurystheus erythrophthalmus

Amphithoë rubricata

Fassa falcata

Caprella acanthifera

Leucothoë incisa

Elasmopus rapax

Microdeutopus damnoniensis

$M$. chelifer

Microjassa cumbrensis

Podocerus variegatus

Caprella linearis
Isle of Man

Stenothoë monoculoides

Apherusa jurinei

Tritaeta gibbosa

Lembos websteri

Eurystheus erythrophthalmus

Amphithoë rubricata

Fassa falcata

Caprella acanthifera

Nannonyx goësi

Orchomene humilis

Gitana sarsi

Leucothoë spinicarpa

Lilljeborgia brevicornis

Apherusa bispinosa

Dexamine thea

Hyale prevosti

Aora typica

Pleonexes gammaroides

fassa ocia

Parajassa pelagica

Ericthonius brasiliensis

Corophium bonelli 
Allowing for the fact that the investigations at Port Erin were more extensive and that a number of species were collected once only the two lists are very similar. Eight out of fifteen species recorded at Plymouth occur in the same habitat at Port Erin, and of the remaining seven Leucothoë incisa, Elasmopus rapax, Microdeutopus chelifer and Podocerus variegatus have not been recorded from the Isle of Man. It is evident that this habitat is an important one, as the population of the holdfasts is often very large. According to Colman there may be as many as 175 amphipods per I00 g. of damp weed. I have several times obtained 300 or more individuals from six medium-sized holdfasts of a total weight of about $300 \mathrm{~g}$.

Goodhart \& Harrison (I940) gave a list of six amphipods found on the shore above L.w.S. at Oldany Harbour, Sutherland. These were Ampelisca spinimana, Harpinia antennaria, Leucothoë spinicarpa, Coremapus versiculatus, Phtisica marina and Caprella acanthifera. With two exceptions they had not been recorded elsewhere between tide-marks. It was suggested as a possible explanation of this distribution that these species occurred above low-water mark only on coasts washed by the North Atlantic Drift.

At Port Erin four of these species occur and they have all been found above low-water mark, Caprella acanthifera sometimes abundantly. Ampelisca spinimana and Coremapus versiculatus have not been recorded from the area. The water near the coasts of the Isle of Man is considerably less saline than unaltered Atlantic water. There is a gradual diminution in surface salinity from St George's Channel towards the Lancashire coast, indicating a drift from south to north through the Irish Sea. The mean value near Port Erin is $34 . \mathrm{I} \%$ (Proudman, 1946). There is probably no current from the North Channel reaching the Isle of Man. In view of these facts I do not think that the hypothesis of Goodhart and Harrison can be maintained.

It is unlikely that temperature or the time of occurrence of spring tides are controlling factors, since spring tides occur during the hottest part of the day in the north of Scotland (Reid, I935).

It is more likely that the intertidal distribution of some amphipods is regulated by the amount of shelter available. All the records of the four species mentioned above in the Isle of Man were from locations affording a good deal of shelter from heavy seas, and which consequently contained a large amount of silt, and it is probably this last factor that the amphipods find favourable. In this connexion it is interesting to note that in Port St Mary Outer Harbour, which is almost completely protected from wave action, the sand at L.W.s. is rather muddy and contains among other species Urothoë elegans, Harpinia antennaria, Perioculodes longimanus and Podalirius typicus, none of which is frequently found above low-water mark.

It is possible that the scarcity of intertidal records from other districts is merely due to the comparative lack of intensive collecting. 


\section{Brackish-Water and Estuarine Habitats}

It will be convenient to describe three locations in the area in which the distribution of the amphipods is affected by variations in salinity.

\section{Spaldrick}

This location is situated at the north side of Port Erin Bay. It consists of a rocky beach with a small fresh-water stream emptying on to the beach over a fall just above H.w.S., and running into the sea through stones and boulders covered with Fucus and Ascophyllum. In the summer the stream is often reduced to a mere trickle. The animals living in the stream are therefore subjected to considerable variations in salinity, especially during spring tides, from almost fresh water at low tide when the stream is in flood to almost full salinity at high tide when the stream is low. In winter the salinity under the fall reaches about $\mathrm{I} 7 \%$ at H.w.S. The whole tidal zone will be subjected to these extremes for varying periods, the inhabitants of the topmost zone living in fresh water for most of the time and those of the lowest zone in sea water except for short periods at L.w.S. The length of the beach from high- to lowwater mark is about 70 yards.

\section{Brewery Beach}

This location is situated just east of Gansey. A fresh-water stream enters the shore through a tunnel just above H.w.S. and runs over rock with scattered stones to below H.W.N., the remainder of its course over the shore being over fine sand with a number of flat stones down to L.W.N. The amphipods occur under the stones. The stream is rather larger than that at Spaldrick. The distance from high- to low-water mark is about I20 yards. Fig. I shows the relative distributions of the amphipod species found in these two streams.

Salinity conditions are approximately the same at both locations.

It will be seen that the zonation of species common to both streams is generally similar. At Spaldrick the presence of Marinogammarus obtusatus and M. finmarchicus may be regarded as accidental since both species are much more abundant outside the limits of the stream. They are evidently able to tolerate almost fresh water for some hours at a time. Hyale prevosti and Melita palmata are also more abundant away from the stream at both locations. Marinogammarus marinus is abundant both in and away from the streams, but extends to a lower level on the shore where there is fresh-water influence. The remaining species are confined to the area of the streams. At both places the brackish-water type of Gammarus duebeni occurs from about H.W.S. to H.W.N. At Spaldrick this species also occurs for some distance up the stream to a height of at least about $100 \mathrm{ft}$. above sea-level. Since the stream enters the shore over a fall there is a distinct break in the distribution of G. duebeni, and presumably the animals found above the fall belong to the fresh-water type. 
The species is apparently absent above the shore at Brewery Beach since a number of collections in the stream failed to produce any. I am unable to give any reason for its absence from the upper reaches.

Marinogammarus pirloti occupies much the same zone as M. marinus at Brewery Beach but is absent from Spaldrick, and Gammarus zaddachi salinus occurs from about M.T.L. to L.w.N. at Brewery Beach but not at Spaldrick. Since the salinity conditions are much the same in both streams some other factor must control their distribution and the most obvious one is the nature of

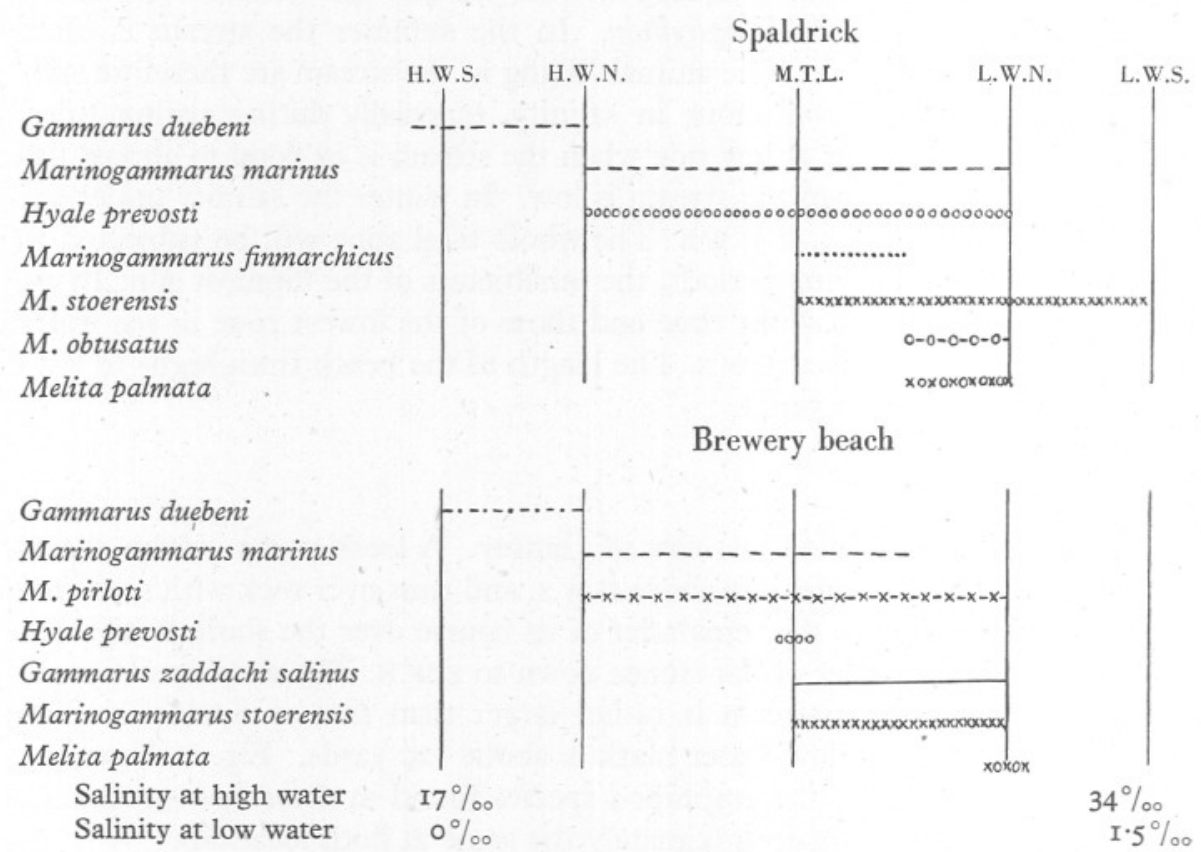

Fig. I. The relative distributions of various amphipods in the streams at Spaldrick and Brewery Beach. The vertical lines indicate the tidal level. Limits for each species are only approximate.

the ground over which the streams flow. At Brewery Beach the stream flows over sand from just below H.w.N. to low-water mark, while at Spaldrick the whole course is over rocks and through boulders. It is possible that Marinogammarus pirloti and Gammarus zaddachi can establish themselves only where fine deposits are present.

\section{The Silverburn}

This is the only stream in the area of this survey with a distinct estuary. It is a small river which enters the sea through Castletown Harbour. At L.w.S. the whole of the estuary is emptied of sea water. The length of the tidal zone is about $\frac{1}{2}$ mile but the upper 400 yards of this zone is tidal only when high tide at 
Liverpool reaches $28 \mathrm{ft}$. or more above datum, that is during H.w.s. This effect is due to the stream passing over a weir above which neap tides do not reach. The amphipod fauna lives among algae and fresh-water vegetation and under stones on the bottom of the stream and on the banks. Those animals which live in the stream below the weir will be subjected to considerable salinity changes twice daily, the range depending on the distance from the

Gammarus pulex

G. duebeni

G. zaddachi zaddachi

Melita pellucida

Corophium volutator

Marinogammarus marinus

Gammarus zaddachi salinus

Hyale prevosti

Melita palmata

Marinogammarus pirloti

M. stoerensis

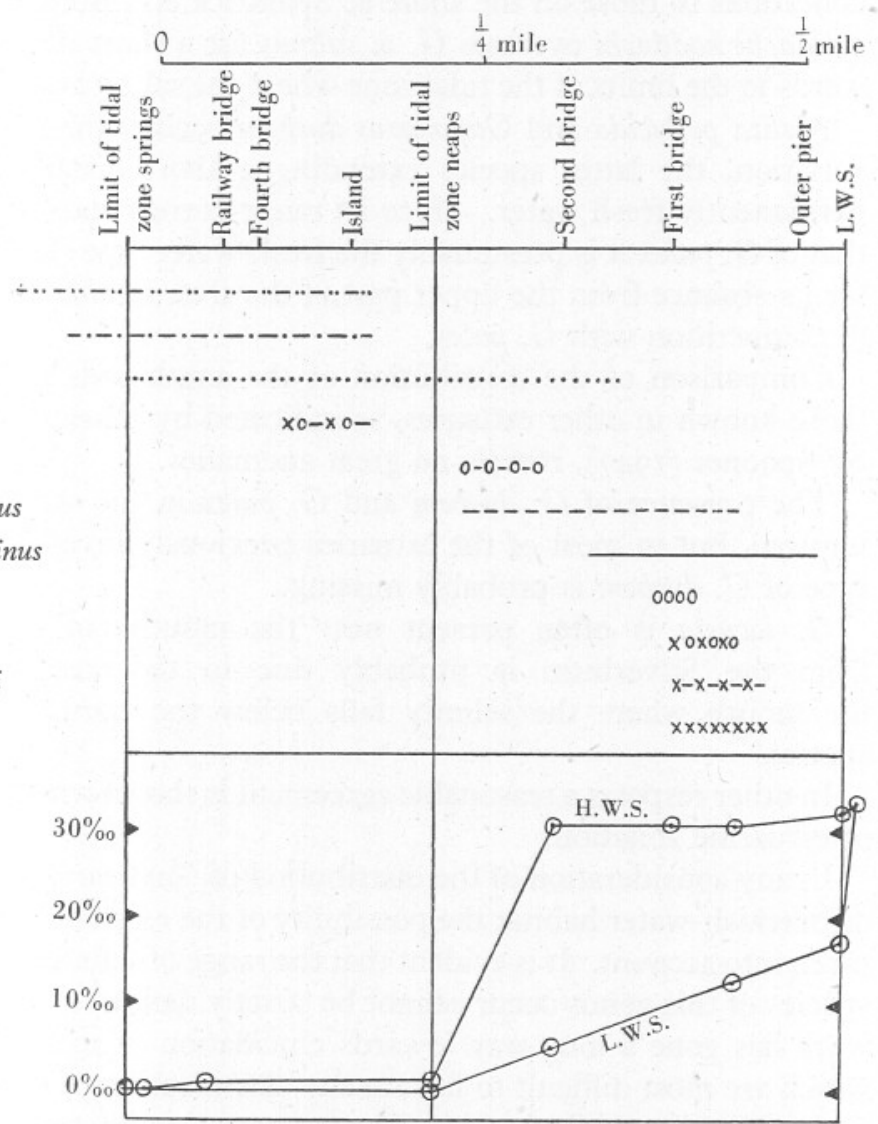

Fig. 2. The relative distribution of the amphipods in the Silverburn. The salinity diagram is based on samples taken near the bottom with a reversing water-bottle.

harbour mouth. Individuals living on the banks above the stream will not experience the lower limits of the salinity range. Above the weir the animals will remain in fresh water for long periods but will at intervals experience a slight rise in salinity. The distribution of the amphipods in the Silverburn is indicated in Fig. 2.

The species which inhabit that part of the estuary which is subjected to a wide range in salinity, i.e. the region below the upper limit of neap tides, 
occupy zones comparable to those which they inhabit on the shore. Marinogammarus marinus, $M$. stoerensis, M. pirloti, Hyale prevosti and Melita palmata are confined to this region. Their distribution may be compared with that shown in Fig. I.

Gammarus zaddachi salinus is confined to the region in which the salinity at high water rises to $33 \%$ at the bottom, and in this respect experiences similar conditions to those on the shore at Spaldrick and Brewery Beach. Gammarus zaddachi zaddachi overlaps G. z. salinus for a short distance but extends upwards to the limits of the tidal zone where the salinity does not rise above $\mathrm{I} \%$ o.

Melita pellucida and Gammarus duebeni occupy the region of small salinity variation, the latter species extending a short distance into the region of permanently fresh water. Since its range corresponds with the lower part of that of G. pulex it is presumably the fresh-water type (Reid, I939). The reason for its absence from the upper part of the river is unknown but it may be due to competition with $G$. pulex.

Comparison of the distribution of the amphipods in the Silverburn with those known in other estuaries, as indicated by Bassindale (1942) and revised by Spooner (1947), reveals no great anomalies.

The presence of $G$. duebeni and $G$. pulex in the same zone appears to be unusual, but in most of the estuaries previously investigated the fresh-water type of $G$. duebeni is probably missing.

G. locusta is often present near the mouths of estuaries. Its absence from the Silverburn is probably due to the steep salinity gradient at the mouth where the salinity falls below the normal lower limit for the species.

In other respects a reasonable agreement is shown with previous descriptions of estuarine zonation.

In any consideration of the distribution of Gammarus species in an estuarine or brackish-water habitat the possibility of the existence of local races must be taken into account. It is evident that the range of salinities in which the various species of this genus occur cannot be strictly defined at present, though recent work has gone a long way towards elucidation of this problem. The species which are most difficult to fit into any classification of habitats are G. duebeni, $G$. zaddachi and G. locusta. There appear to be two types of $G$. duebeni adapted respectively to brackish and fresh water, but they cannot be separated by any morphological criterion (Reid, 1939). G. zaddachi, on the other hand, may be grouped according to external characters into three subspecies (Spooner, 1947, and Segerstråle, I947). G. locusta is a marine species and is usually intolerant of salinities below about $28 \%$ o but in some locations, as in the Baltic (Segerstrale, 1946), it lives in greatly reduced salinities.

It seems probable that the genus Gammarus is in a state of active evolution. There is evidently more than one form of each of the three species mentioned and even where no alteration in external characters has taken place there 
appear to be physiological races. Huxley (1942, p. 279) suggested that the explanation of the occurrence of $G$. duebeni in the fresh waters of Ireland lies in its adoption of a peculiar habitat in atypical conditions at the margin of its range, an occurrence that has been observed in other animals. Salinity is the most obvious factor controlling the evolution of races in the genus and it is not unlikely that in regions of very gradual salinity change forms have evolved which are adapted to different conditions from those in which the parent species is found. These forms may then be able to colonize new areas and, in the absence of interspecific competition, to establish themselves. The presence of $G$. duebeni in the fresh waters of Ireland and its virtual absence from those of England may be due to the fact that $G$. pulex is a more successful competitor but has never become established in Ireland.

The manner in which an amphipod adapted to brackish water extends its range is unknown. There is no possibility of transport of the eggs since they are always carried by the female until hatched. Some species can tolerate high salinities for long periods and can even be bred in sea water in the laboratory (Sexton, I928), and it is possible that they may occasionally be carried from one estuary to another by way of the sea; however, there are few authentic records of the capture of brackish-water species under fully marine conditions. The most probable method of transport from one brackish-water situation to another is on the bodies of birds as suggested by Segerstråle (I946).

\section{SUMMARY}

A survey was made during 1946 covering the Amphipoda of the south end of the Isle of Man from an ecological aspect. The object was to revise the records of the area and to obtain additional information about the habitats of the species found.

The area in which the survey took place was within a radius of 10 miles from Port Erin.

Various sorts of gear were used for collection offshore and it is concluded that the fine-meshed dredge is the most useful instrument for collecting amphipods.

A systematic treatment of the species found includes a summary of records regarding habitat for each species.

It is suggested that the Amphipoda may be of greater economic importance than has previously been realized.

A discussion of offshore, intertidal, and brackish-water habitats includes lists of the more important species obtained grouped according to type of ground and zonation with regard to tidal level and salinity. The importance of offshore species is assessed on a basis of the average number of individuals collected per haul. 
Comparison of the zonation of littoral and estuarine species with that known from other areas reveals a general agreement.

The existence of more than one form of several species of the genus Gammarus is discussed and it is suggested that they are in an active state of evolution.

I am indebted to Prof. J. H. Orton for encouragement and discussion, and to Mr G. M. Spooner for allowing me to read a proof of his recent paper.

\section{REFERENCES}

BAssindale, R., 1942. The distribution of amphipods in the Severn Estuary and Bristol Channel. Fourn. Anim. Ecol., Vol. xI, pp. I3I-44.

BEANLAND, F. L., I940. Sand and mud communities in the Dovey Estuary. Fourn. Mar. Biol. Assoc., Vol. xxiv, pp. 608-10.

Chevreux, E. \& FAge, L., I925. Amphipodes. Faune de France, Vol. Ix, 488 pp. Paris.

Colman, J., 1940. On the faunas inhabiting intertidal seaweeds. Fourn. Mar. Biol. Assoc., Vol. xxiv, pp. I29-83.

CraWford, G. I., I936. Additions to the Plymouth Marine Fauna (I93I) in the crustacean orders Tanaidacea, Isopoda and Amphipoda. Fourn. Mar. Biol. Assoc., Vol. xxI, pp. 95-106.

- I937a. A review of the amphipod genus Corophium with notes on the British species. Fourn. Mar. Biol. Assoc., Vol. xxI, pp. 589-630.

— 1937 b. Notes on the distribution of burrowing Isopoda and Amphipoda in various soils on the sea bottom near Plymouth. Fourn. Mar. Biol. Assoc., Vol. xxI, pp. $63 \mathrm{I}-46$.

- I937c. The faunas of certain estuaries in West England and South Wales, with special reference to the Tanaidacea, etc. Fourn. Mar. Biol. Assoc., Vol. xxI, pp. 647-62.

EDWARDS, G. A. \& IRvING, L., I943. The influence of season and temperature upon the oxygen consumption of the beach flea, Talorchestia megalophthalma. Fourn. Cellular and Comparative Physiology, Vol. xxI, pp. I83-9.

ElmHIRST, R., I93I. Studies in Scottish marine fauna-Crustacea of sandy and muddy areas of the tidal zone. Proc. Roy. Soc. Edin., Vol. LI, pp. I69-75.

ForD, E., I923. Animal communities of the level sea-bottom in the waters adjacent to Plymouth. Fourn. Mar. Biol. Assoc., Vol. xIII, pp. I64-224.

GOODHART, C. B. \& HARRISON, R. J., I940. Occurrence of some offshore amphipods in the littoral zone. Nature, Vol. cxLv, p. Io9.

Harrison, R. J., 1944. Synopses of the British Fauna. No. 2. Caprellidea. Linn. Soc. London.

HaRt, T. J., I930. Preliminary notes on the bionomics of the amphipod, Corophium volutator (Pallas). Fourn. Mar. Biol. Assoc., Vol. xvi, pp. 765-9.

HunT, O. D., I925. The food of the bottom fauna of the Plymouth fishing grounds. fourn. Mar. Biol. Assoc., Vol. xIII, pp. 560-99.

HuxLEy, J. S., 1942. Evolution-the Modern Synthesis. London.

JoNES, N. S., I940. The distribution of the marine fauna and bottom deposits off Port Erin. Trans. Liverpool Biol. Soc., Vol. LIII, pp. I-34.

Marine Biological Association, i93r. Plymouth Marine Fauna (2nd edition).

Moore, H. B., I937. Marine fauna of the Isle of Man. Trans. Liverpool Biol. Soc., Vol. L, pp. II $7-28$. 
Norman, A. M. \& ScotT, T., 1906. The Crustacea of Devon and Cornwall. London. Pp. vii-x.

PIRLOT, J.-M., I932a. Introduction à l'étude des amphipodes hypérides. Annales de l'Institute Océanogr. Nouv. Sér., T. XII, fasc. I.

- I932 $b$. Sur quelques amphipodes associés aux colonies de tubulaires dans la région de Bergen. Bulletin de la Soc. Royale des Sciences de Liège, T. I, fasc. I.

_ 1932 c. Les amphipodes fouisseurs, Phoxocephalidae, Oedicerotidae. SibogaÉxpeditie, Vol. xxxIII $b$.

Proudman, J., I946. On the surface salinity of the Irish Sea. Phil. Trans. Roy. Soc., A, Vol. 239, pp. 579-92.

ReIBISCH, J., I905-6. Faunistisch-biologische Untersuchungen über Amphipoden der Nordsee. Wiss. Meeresunters., Abt. Kiel, Vol. vin, pp. I47-88 and Ix, pp. I85237.

ReID, D. M., I935. The range of the sea urchin Echinus esculentus. Fourn. Anim. Ecol., Vol. IV, pp. 7-I6.

- 1939. On the occurrence of Gammarus duebeni (Lillj.) in Ireland. Proc. Roy. Irish Acad., B, Vol. xLV, pp. 207-I4.

- 1944. Synopses of the British Fauna. No. 3. Gammaridae. Linn. Soc. London.

Russell, F. S., 1928. A net for catching plankton near the bottom. Fourn. Mar. Biol. Assoc., Vol. xv, pp. 105-8.

Sars, G. O., I895. An Account of the Crustacea of Norway. I. Amphipoda. Oslo.

SEGERSTRÅLE, S. G., I946. On the occurrence of the amphipod Gammarus duebeni (Lillj.) in Finland, with notes on the ecology of the species. Soc. Scient. Fennica, Comment. Biol., Ix, No. I8.

- 1947. New observations on the distribution and morphology of the amphipod Gammarus zaddachi Sexton etc. Fourn. Mar. Biol. Assoc., Vol. xxviI, pp. 21944.

Sexton, E. W., I928. On the rearing and breeding of Gammarus in laboratory conditions. Fourn. Mar. Biol. Assoc., Vol. xv, pp. 33-55.

Sexton, E. W. \& Spooner, G. M., I940. An account of Marinogammarus (Schellenberg), etc. Fourn. Mar. Biol. Assoc., Vol. xxiv, pp. 633-82.

Southern, R., I915. Marine ecology. Clare Island Survey, pt. 67. Proc. Roy. Irish Acad., Vol. xxxi.

Spooner, G. M., I947. The distribution of Gammarus species in estuaries. Part I. fourn. Mar. Biol. Assoc., Vol. xxvII, pp. I-52.

Stephensen, K., I929. Amphipoda. Tierwelt der Nord-und Ostsee, Lief. xIv, Teil X.f.

- r.935-42. The Amphipoda of N. Norway and Spitsbergen with adjacent waters. I-IV. Tromsö Museums Skr., Vol. III.

Steven, G. A., I930. Bottom fauna and the food of fishes. Fourn. Mar. Biol. Assoc., Vol. xvi, pp. 667-706.

Tattersall, W. M., I9I3. Amphipoda. Clare Island Survey, pt. 42. Proc. Roy. Irish Acad., Vol. xxxI, pp. 22-4.

Walker, A. O., I895. Revision of the Amphipoda of the L.M.B.C. district. Fauna of Liverpool Bay, Rep. Iv, pp. 415-48.

—— IgI I. Notes on Fassa falcata (Mont.). Trans. Liverpool Biol. Soc., Vol. xxv, pp. 67-72.

WATKIN, E. E., I94I. Observations on the night tidal migrant crustacea of Kames Bay. Fourn. Mar. Biol. Assoc., Vol. xxv, pp. 8I-96. 


\section{APPENDIX I}

\section{Additions to the Fauna of the IsLe of MaN}

The following species are here recorded for the first time from the area:

Acidostoma obesum (Bate)

Nannonyx spinimanus Walker

Tryphosa sarsi Bonnier

Tryphosites longipes (Bate \& Westwood)

Ampelisca diadema (Costa)

Bathyporeia gracilis G. O. Sars

Urothoë elegans. Bate

Harpinia pectinata G. O. Sars

Amphilochus spence-batei Stebbing

Metopa borealis G. O. Sars

M. pusilla G. O. Sars

Laphystius sturionis Kröyer

Monoculodes subnudus Norman

Calliopius crenulatus Chevreux \& Fage

Parapleustes monocuspis (G. O. Sars)

Epimeria cornigera (J. C. Fabricius)

Cheirocratus intermedius G. O. Sars

Melita hergensis Reid
Gammarus pulex (L.)

Marinogammarus finmarchicus (Dahl)

M. stoerensis (Reid)

Pectenogammarus planicrurus Reid

Microdeutopus damnoniensis Bate

Eurystheus melanops (G. O. Sars)

Protomedeia fasciata Kröyer

Isaea montagui Milne-Edwards

Sunamphithoë pelagica (Milne-Edwards)

Biancolina cuniculus Stebbing

Unciola planipes Norman

Corophium crassicorne Bruzelius

C. affine Bruzelius

Parvipalpus capillaceus (Chevreux)

Caprella acutifrons Latreille

C. fretensis Stebbing

Themisto abyssorum (Boeck) 


\section{APPENDIX II \\ OTHER RECORDS AND CORRECTIONS}

The following species have been recorded from the area previously but were not collected during the course of this survey:

Normanion quadrimanus (Bate \& Westwood)

Harpinia laevis G. O. Sars

Peltocoxa marioni Catta
Parapleustes assimilis (G. O. Sars)

Calliopius laeviusculus Kröyer

Ericthonius difformis Milne-Edwards

Siphonoecetes colleti Boeck

The following species have been recorded incorrectly from the area (Marine Fauna of the Isle of Man, 1937, and additions in Annual Reports, Marine Biological Station, Port Erin):

Amphilochoides odontonyx Boeck. Walker's original record was named in accordance with Sars (1895), and should have been referred to A. serratipes (Norman).

Apherusa ovalipes Norman \& Scott. Examination of the specimens in the collection referred to this species shows that they are all $A$. bispinosa (Bate).

Gammarus campylops Leach. These were probably immature specimens of G. locusta and possibly of G. zaddachi. G. campylops is now a doubtful species (Sexton \& Spooner, I940).

Leptocheirus pilosus Zaddach. Walker's original record refers to L. pectinatus Norman.

fassa dentex (Czerniavski). The forms referred to this species should now be included under F. falcata (Montagu). 


\section{APPENDIX III}

\section{Record of Hauls taken OfFshore}

\begin{tabular}{|c|c|}
\hline $\begin{array}{c}\text { Serial } \\
\text { no. }\end{array}$ & Date \\
\hline I & 29. iii. 4 \\
\hline 2 & 8. iv. 4 \\
\hline 4 & ro. iv. \\
\hline 5 & I2. iv. 4 \\
\hline 6 & I2. iv. 4 \\
\hline 7 & I6. iv. 4 \\
\hline 8 & I7. iv. \\
\hline 9 & 24. iv. \\
\hline IO & 24. iv. 4 \\
\hline II & 25. iv. \\
\hline 12 & 26. iv. 4 \\
\hline I3 & 26. iv. 46 \\
\hline I4 & I. v. 46 \\
\hline I6 & 3. v. 46 \\
\hline I7 & 3. v. 46 \\
\hline I8 & 8. v. 46 \\
\hline I9 & Io. v. 46 \\
\hline 20 & Io. v. 46 \\
\hline $2 I$ & I3. v. 46 \\
\hline 22 & I3. v. 46 \\
\hline 23 & I5. v. 46 \\
\hline
\end{tabular}

Position
$\frac{3}{4}$ mile W. of Bradda Head
$\frac{3}{4}$ mile N. of Kitterland
$\frac{1}{2}$ mile N. of Fleshwick
I mile N. of Kitterland
Inside Port Erin Bay
$\frac{3}{4}$ mile N.W. of Bay Fine

Coarse sand

Stony gravel

Inside Port Erin Bay

$\frac{1}{2}$ mile W.S.W. of Bradda

I mile W.N.W. of Bradda

Inside Port Erin Bay

$\mathrm{I}_{2}^{\frac{1}{2}}$ miles W.N.W. of Bradda

3 miles W.N.W. of Charran

Mouth of Port Erin Bay

2 miles W.N.W. of Charran

$\frac{1}{2}$ mile N.W. of Fleshwick

Off Raglan Pier, Port Erin

Bay

50 yards off Bay Fine

N. side of Port Erin Bay

2 miles W.N.W. of Bradda
Type of bottom or contents of haul

Algae on sand and broken shell

Coarse sand and broken shell

Fine sand with algae

Hydroids on broken shell

Coarse sand and broken

shell

Fine sand with algae

Fine sand with weed

Coarse sand and broken shell

No. of

species

I

5

8

7

7

I2

Muddy sand and broken shell

Algae on sand

Muddy sand and broken shell

Muddy sand and broken shell

Fine sand with algae

Muddy sand and broken shell

Fine sand with weed

Fine sand with weed

Sand and stony gravel

Fine gravel and sand

Muddy sand and broken shell

\begin{tabular}{|c|c|c|}
\hline $\begin{array}{l}\text { No. of } \\
\text { individuals }\end{array}$ & $\begin{array}{l}\text { Depth } \\
\text { (m.) }\end{array}$ & Gear used \\
\hline $\mathbf{I}$ & 27 & Naturalist's dredge \\
\hline I3 & 22 & N.D. \\
\hline II9 & I5 & $\begin{array}{l}\text { Small fine-meshed } \\
\text { dredge }\end{array}$ \\
\hline 36 & 27 & N.D. \\
\hline 22 & $6-9$ & Small F.-M.D. \\
\hline 71 & 27 & N.D. \\
\hline $6 I$ & 27 & N.D. \\
\hline 24 & $9-13$ & D-net \\
\hline 36 & $4-9$ & D-net \\
\hline I4 & 29 & N.D. \\
\hline 9 & 29 & D-net \\
\hline 34 & $4-9$ & D-net \\
\hline I4 & 33 & N.D. \\
\hline 21 & 33 & Small F.-M.D. \\
\hline 27 & $9-13$ & D-net \\
\hline 46 & $3 I$ & Small F.-M.D. \\
\hline $\begin{array}{r}5 \\
158\end{array}$ & $\begin{array}{c}\text { II }- \text { I5 } \\
2-4\end{array}$ & $\begin{array}{l}\text { Small F.-M.D. } \\
\text { Small F.-M.D. }\end{array}$ \\
\hline $\begin{array}{r}170 \\
68\end{array}$ & $\begin{array}{l}\text { I I-I5 } \\
\text { I } 8-I I\end{array}$ & Small F.-M.D. \\
\hline 40 & 33 & Small F.-M.D. \\
\hline
\end{tabular}




\begin{tabular}{|c|c|c|c|c|c|c|c|}
\hline 24 & I7. v. 46 & 50 yards off Bradda & Stony gravel & 4 & 7 & $22-27$ & Small F.-M.D. \\
\hline 26 & 2o. v. 46 & N. side of Port Erin Bay & Fine gravel and sand & 29 & II 4 & $7-15$ & Small F.-M.D. \\
\hline 27 & 20. $v_{s} 46$ & $\begin{array}{l}\text { Inside Port Erin } \\
\text { Breakwater }\end{array}$ & Fine sand with weed & 28 & 156 & II & Small F.-M.D. \\
\hline 28 & 24. v. 46 & $\begin{array}{l}6 \text { miles W.N.W. of } \\
\text { Fleshwick }\end{array}$ & Muddy sand & 6 & 20. & 46 & Small F.-M.D. \\
\hline 29 & I4. vi. 46 & 400 yards off Bay Fine & Sand and fine stony gravel & I5 & 22 & I8 & Small F.-M.D. \\
\hline 30 & I4. vi. 46 & Off Raglan Pier & Fine sand with weed & 5 & 162 & $2-4$ & Small F.-M.D. \\
\hline $3 \mathrm{I}$ & I5. vi. 46 & $\begin{array}{l}\text { Bay Fine to Port Erin } \\
\text { Breakwater }\end{array}$ & Algae on sand and gravel & 5 & 6 & I8-II & Otter trawl \\
\hline 32 & I9. vi. 46 & $\frac{3}{4}$ mile W.N.W. of Bradda & $\begin{array}{l}\text { Muddy sand and broken } \\
\text { shell }\end{array}$ & 25 & $8 \mathrm{I}$ & 29 & Small F.-M.D. \\
\hline 33 & I9. vi. 46 & N. side of Port Erin Bay & Sand and fine gravel & I8 & 76 & I5-18 & Small F.-M.D. \\
\hline 34 & 2I. vi. 46 & $2 \frac{1}{2}$ miles W. of Bradda & $\begin{array}{l}\text { Muddy sand and broken } \\
\text { shell }\end{array}$ & 24 & 46 & 33 & Small F.-M.D. \\
\hline 35 & 21. vi. 46 & $\begin{array}{l}\text { I } \frac{1}{2} \text { miles W. by N. of } \\
\text { Bradda }\end{array}$ & $\begin{array}{l}\text { Muddy sand and broken } \\
\text { shell }\end{array}$ & 9 & I5 & $3 I$ & Small F.-M.D. \\
\hline 36 & 24. vi. 46 & 2 miles N.W. of Kitterland & $\begin{array}{l}\text { Coarse sand and broken } \\
\text { shell }\end{array}$ & I8 & 60 & $3 \mathrm{I}$ & Small F.-M.D. \\
\hline 37 & 24. vi. 46 & $\begin{array}{l}2 \frac{1}{2} \text { miles N. by W. of } \\
\text { Kitterland }\end{array}$ & $\begin{array}{l}\text { Muddy sand and broken } \\
\text { shell }\end{array}$ & Io & 24 & 33 & Small F.-M.D. \\
\hline 38 & 26. vi. 46 & $\begin{array}{l}2 \frac{1}{2} \text { miles W.N.W. of } \\
\text { Kitterland }\end{array}$ & $\begin{array}{l}\text { Muddy sand and broken } \\
\text { shell }\end{array}$ & 9 & 12 & $3 I$ & Small F.-M.D. \\
\hline 39 & 26. vi. 46 & $\begin{array}{l}2 \text { miles W.N.W. of } \\
\text { Charran }\end{array}$ & $\begin{array}{l}\text { Muddy sand and broken } \\
\text { shell }\end{array}$ & 13 & 30 & 33 & Small F.-M.D. \\
\hline 40 & I. vii. 46 & $\begin{array}{l}\frac{1}{2} \text { mile N.N.W. of Calf } \\
\text { Stack }\end{array}$ & $\begin{array}{l}\text { Coarse sand and broken } \\
\text { shell }\end{array}$ & 20 & I 28 & 33 & Small F.-M.D. \\
\hline $4 \mathrm{I}$ & I. vii. 46 & Bay Fine to Breakwater & Algae on sand and gravel & 5 & I5 & I8-II & Otter trawl \\
\hline 42 & 3. vii. 46 & $3 \frac{1}{2}$ miles W. of Bradda & Coarse sand & 6 & 33 & 35 & Small F.-M.D. \\
\hline 43 & 8. vii. 46 & $\begin{array}{l}3 \text { miles N. by W. of Calf } \\
\text { Stack }\end{array}$ & $\begin{array}{l}\text { Hydroids on coarse sand } \\
\text { and shells }\end{array}$ & 6 & Io & 33 & Small F.-M.D. \\
\hline 44 & 8. vii. 46 & 2 miles W. by S. of Bradda & $\begin{array}{l}\text { Coarse sand and broken } \\
\text { shell }\end{array}$ & 8 & II & $3 \mathrm{I}$ & Small F.-M.D. \\
\hline 45 & Io. vii. 46 & Bradda Head to Breakwater & Algae on fine sand & 6 & 42 & I8-II & Otter trawl \\
\hline 46 & II. vii. 46 & Bay Fine to Breakwater & Algae on sand and gravel & 8 & 29 & I8-II & Otter trawl \\
\hline 48 & I2. vii. 46 & $\frac{1}{2}$ mile N. of Fleshwick & Fine stony gravel & I4 & $\mathrm{I}_{32}$ & II -15 & Small F.-M.D. \\
\hline
\end{tabular}




\section{APPENDIX III (cont.)}

\begin{tabular}{|c|c|}
\hline $\begin{array}{c}\text { Serial } \\
\text { no. }\end{array}$ & Date \\
\hline 49 & I6. vii. 46 \\
\hline 50 & I6. vii. 46 \\
\hline 51 & 24. vii. 46 \\
\hline 53 & 26. vii. 46 \\
\hline 54 & I. viii. 46 \\
\hline 55 & I. viii. 46 \\
\hline 56 & 8. viii. 46 \\
\hline 57 & 8. viii. 46 \\
\hline $5^{8}$ & I6. viii. 46 \\
\hline 59 & I6. viii. 46 \\
\hline 60 & I6. viii. 46 \\
\hline $6 \mathrm{I}$ & 20. viii. 46 \\
\hline 62 & 20. viii. 46 \\
\hline 63 & 21. viii. 46 \\
\hline 64 & 26. viii. 46 \\
\hline 65 & 26. viii. 46 \\
\hline 66 & 26. viii. 46 \\
\hline 67 & 2. ix. 46 \\
\hline 68 & 2. ix. 46 \\
\hline 69 & 4. ix. 46 \\
\hline 70 & II. ix. 46 \\
\hline 71 & 20. ix. 46 \\
\hline 72 & 20. ix. 46 \\
\hline 73 & 24 . ix. 46 \\
\hline 74 & $25 . \mathrm{ix} .46$ \\
\hline
\end{tabular}

Position

$\frac{1}{2}$ mile N. of Bay Fine

Mouth of Port Erin Bay

2 miles S. of Kitterland

$\frac{3}{4}$ mile W. of Bradda

5 miles N.W. by W. of

Bradda

5 miles N.W. by W. of

Bradda

6 miles W. of Port Erin

6 miles W. of Port Erin

$\mathrm{I} \frac{1}{2}$ miles W.N.W. of

Bradda

Bradda Head to

Breakwater

Bay Fine to Breakwater

3 miles S.E. of Kitterland

3 miles S.E. of Kitterland

$2 \frac{1}{2}$ miles W. of Port Erin

8 miles W.N.W. of Port

Erin

8 miles W. $\frac{1}{2}$ N. of Bradda

8 miles W. by N. of Bradda

5 miles S. of Spanish

Head

5 miles S. of Spanish

Head

Bay Fine to Breakwater

Bay Fine to Breakwater

Mouth of Port Erin Bay

Mouth of Port Erin Bay

I mile N. of Bay Fine

400 yards off Bay Fine
Type of bottom or

contents of haul

Sand and fine gravel

Fine sand with weed

Hydroids on shell gravel

Nemertesia on shell

Muddy sand

Hydroids on muddy sand

Muddy sand

Hydroids on muddy sand

Muddy sand and broken shell

Algae on sand

Algae on sand and gravel

Hydroids on stones

Hydroids on stones and gravel

Coarse sand and broken

shell

Mud

Muddy sand

Hydroids on muddy sand

Sponges on Modiolus

Hydroids on Modiolus

Sand and fine stony gravel

Sand and gravel

Fine sand with weed

Algae on sand

Coarse sand and broken shell

Sand and fine gravel
No. of No. of Depth species individuals (m.)

7

I0

4

7

I4

9
Gear used

Small F.-M.D.

Small F.-M.D.

Otter trawl

On long line

Large F.-M.D.

Scallop dredge

Large F.-M.D.

S.D.

Large F.-M.D.

Otter trawl

Otter trawl

S.D.

Large F.-M.D.

Large F.-M.D.

Young fish trawl

Large F.-M.D.

Otter trawl

N.D.

N.D.

Bottom tow-net

Bottom tow-net

Bottom tow-net

Otter trawl

Large F.-M.D.

Large F.-M.D. 


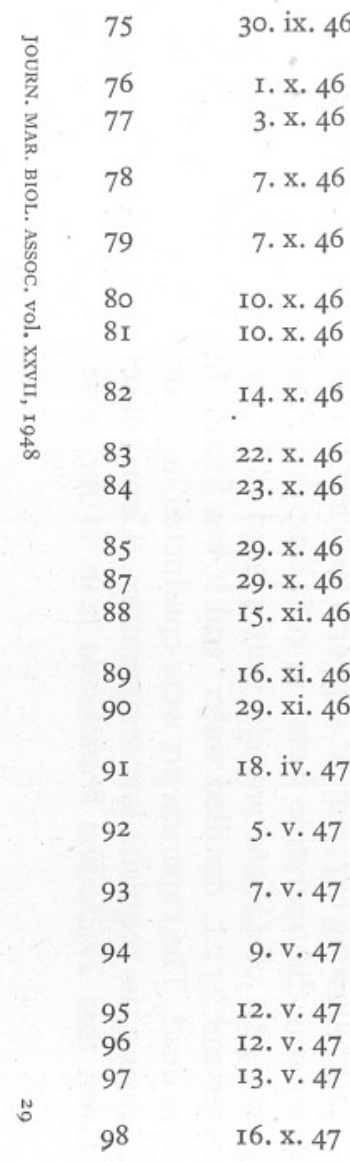

$4 \frac{1}{2}$ miles S.W. by W. of Calf Stack

I $\frac{1}{2}$ miles W. of Charran

$8 \frac{1}{2}$ miles N.W. by N. of

Bradda

3 miles W.N.W. of Dalby

$\frac{1}{2}$ mile W. of Cronk-nyArrey-Laa

50 yards off S.W. of Calf

I $\frac{1}{2}$ miles N. of Calf Stack

$2 \frac{1}{2}$ miles W.N.W. of

Charran

400 yards N. of Bay Fine

$\frac{1}{2}$ mile W. of Bradda

Breakwater to Castle Rock

Inside Port Erin Bay

$\frac{1}{2}$ mile N. of Bay Fine

Inside Port Erin Bay

$2 \frac{1}{2}$ miles W. by S. of

Bradda

I $\frac{1}{2}$ miles N. of Kitterland

$2 \frac{1}{2}$ miles N.W. of Bradda

2 miles W.N.W. of Bradda

I mile N.W. of Bay Fine

Inside Port Erin Bay

Off Castle Rock

$5 \frac{1}{2}$ miles N.W. by W. of

Bradda

9 miles W.N.W. of Bradda
Coarse sand and broken

shell

Muddy sand

Mud

Muddy sand and broken shell

Fine stony gravel

Coarse sand

Hydroids on sand and

shells

Muddy sand and broken

shell

Submerged wood

Muddy sand and broken shell

Sand and fine gravel

Fine sand

Algae on sand and broken

shell

On dead fish

Coarse sand and broken

shell

Coarse sand and broken

shell

Muddy sand and broken

shell

Muddy sand and broken

shell

Coarse sand and broken shell

Fine sand

Sand and fine gravel

Muddy sand

Mud
Large F.-M.D.

Large F.-M.D.

Large F.-M.D.

Large F.-M.D.

Large F.-M.D.

Large F.-M.D. N.D.

\section{Large F.-M.D.}

Otter trawl

Large F.-M.D.

Bottom tow-net

Large F.-M.D. S.D.

\section{Lobster pot}

Large F.-M.D.

Large F.-M.D.

Large F.-M.D.

Large F.-M.D.

Large F.-M.D.

Large F.-M.D.

Large F.-M.D.

Large F.-M.D.

$84 \quad$ Young fish trawl 